\title{
Heat and salinity transport between the permanent pycnocline and the mixed layer due to the obduction process evaluated from a gridded Argo dataset
}

\author{
Yoshimi Kawai $^{1}\left[\right.$ Shigeki Hosoda ${ }^{1} \cdot$ Kazuyuki Uehara $^{2} \cdot$ Toshio Suga $^{1,3}$
}

Received: 30 March 2020 / Revised: 21 July 2020 / Accepted: 26 July 2020 / Published online: 9 August 2020

(c) The Author(s) 2020

\begin{abstract}
It is necessary for air-sea interaction and climate research to evaluate heat and salinity transport between the mixed layer (ML) and the permanent pycnocline and its contribution to the ML properties. The authors have calculated the obduction and subduction rates with the Eulerian definition using a $1^{\circ}$-grid Argo dataset and incorporated the obduction rate into the ML budget analysis in order to assess the impact of the entrained permanent pycnocline water on the ML temperature and salinity. They have successfully separated the effect of obduction on the ML from the entrainment of the seasonal pycnocline, and specified the regions where the obduction impact is noticeable. The ML heating rate due to obduction was smaller than $\pm 0.1 \mathrm{~K} / \mathrm{yr}$ on average over most of the domain, but it was larger than $-0.5 \mathrm{~K} / \mathrm{yr}$ in places around the Circumpolar Current, in the northeastern tropical Pacific, the southwestern tropical Indian Ocean, and the northeastern North Atlantic. The salinizing rate due to obduction exceeded $\pm 0.02 \mathrm{psu} / \mathrm{yr}$ in these areas, and in the subarctic North Pacific and the eastern South Pacific. The waters entrained from the permanent pycnocline warm and salinize the ML in the high latitudes due to the dichothermal structure. The method applied in this study also enabled us to assess the residence time and route of obducted and subducted water parcels below the ML. Furthermore, the authors examined the changes of obduction and subduction related with the marine heatwave that occurred in the northeastern North Pacific around 2014.
\end{abstract}

Keywords Obduction $\cdot$ Mixed layer $\cdot$ Budget $\cdot$ Argo float $\cdot$ Marine heatwave

\section{Introduction}

The heat content of the global upper ocean above $700 \mathrm{~m}$ has been increasing since 1970s mainly due to the increase of carbon dioxide and other greenhouse gases in the atmosphere (e.g. Levitus et al. 2012; Rhein et al. 2013). Repeat hydrographic surveys revealed that the warming already spread to the global abyssal waters (Kouketsu et al. 2011). Besides the long-term warming trend, extreme high sea

Yoshimi Kawai

ykawai@jamstec.go.jp

1 Research Institute for Global Change, Japan Agency for Marine-Earth Science and Technology, 2-15 Natsushima-Cho, Yokosuka 237-0061, Japan

2 School of Marine Science and Technology, Tokai University, 3-20-1 Orido, Shimizu-ku, Shizuoka 424-8610, Japan

3 Graduate School of Science, Tohoku University, 6-3 Aoba, Aramaki-aza, Aoba-ku, Sendai 980-8578, Japan surface temperature (SST) events that persist for days to months within a limited region, which are referred to as "marine heatwaves", often occur. The frequency and duration of the marine heatwave events are expected to increase under global warming (Frölicher et al. 2018; Oliver et al. 2018). Extreme warming with a relatively short period may affect the ocean circulation. The exchanges of heat, salinity, and materials between the ocean upper layer and the interior, however, have not been investigated sufficiently.

The ocean mixed layer (ML) in the extratropics usually becomes deepest in winter or early spring due to strong surface cooling and wind stress. In the following warm season, the seasonal pycnocline is formed above the permanent pycnocline, and the layer between the shallow ML and permanent pycnocline is isolated from the atmosphere. While some part of the isolated layer is entrained into the ML again in the following winter, the other part is transported along an isopycnal surface into the permanent pycnocline irreversibly. The latter process is referred to as subduction, one of the major processes by which properties of the upper layer 
facing the atmosphere are transferred into the ocean interior. A layer of the nearly vertically homogeneous water below the seasonal thermocline found over a relatively large geographical area is defined as mode water (Hanawa and Talley 2001), and mode waters are regarded as substantial reservoirs of heat and carbon dioxide that play an important role in climate (e.g. Bates 2012; Sugimoto et al. 2017). Subduction rate is large in the mode water formation areas around the world (e.g. Qiu and Huang 1995; Liu and Huang 2012).

The opposite process of subduction is obduction: water of the permanent pycnocline is entrained into the ML when it deepens in autumn and winter. This process is expected to be important for the atmosphere, especially its long-term variations, since it brings anomalies of temperature, carbon dioxide, and other properties in the ocean interior to the surface layer. Subduction and obduction rates are great in regions where the wintertime ML becomes deeper, but obduction does not necessarily occur where subduction does, and vice versa. For example, the southwestern Bering Sea is one of the regions with large obduction rate but with quite small subduction rate (Liu and Huang 2012; Toyama et al. 2015).

The budget of the ML consists of five components: surface forcing, Ekman advection, geostrophic advection, entrainment, and residual (e.g. Qiu and Kelly 1993; Ren and Riser 2009). The residual term here includes vertical and horizontal diffusions. The sum of these five terms is equal to the temporal change rate of a quantity such as temperature and salinity. The entrainment in ML deepening is further separated into two components: the erosion of the permanent pycnocline and that of the seasonal pycnocline (Fig. 1). The former is obduction, and the latter means that the water in contact with the atmosphere in the previous winter is again entrained into the ML within 1 year, which is referred to as "re-entrainment" in this paper and substantially equivalent to "reemergence". The reemergence is the phenomenon that the SST anomaly (SSTA) formed in the previous winter emerges to the sea surface in the following winter due to re-entrainment of the water of the previous-winter ML below the summertime ML. In this paper we define "re-entrainment" and "reemergence" as a process done only above the permanent pycnocline on a scale of 1 year, different from "obduction" that has a time scale longer than 1 year.

A number of previous studies have shown that wintertime SSTAs in some mid-latitude regions recur in the following winter (e.g. Namias and Born 1970; Alexander and Deser 1995; de Coëtlogon and Frankignoul 2003; Hanawa and Sugimoto 2004; Sugimoto and Hanawa 2005; Byju et al. 2018). Numerical experiments and observations, for example, indicated that the reemerging SSTA in the North Atlantic Ocean contributed to the persistence of the North Atlantic Oscillation, altering the occurrence of weather patterns over Europe (Cassou et al. 2007; Taws et al. 2011). These studies suggest the reemergence is one of the important processes

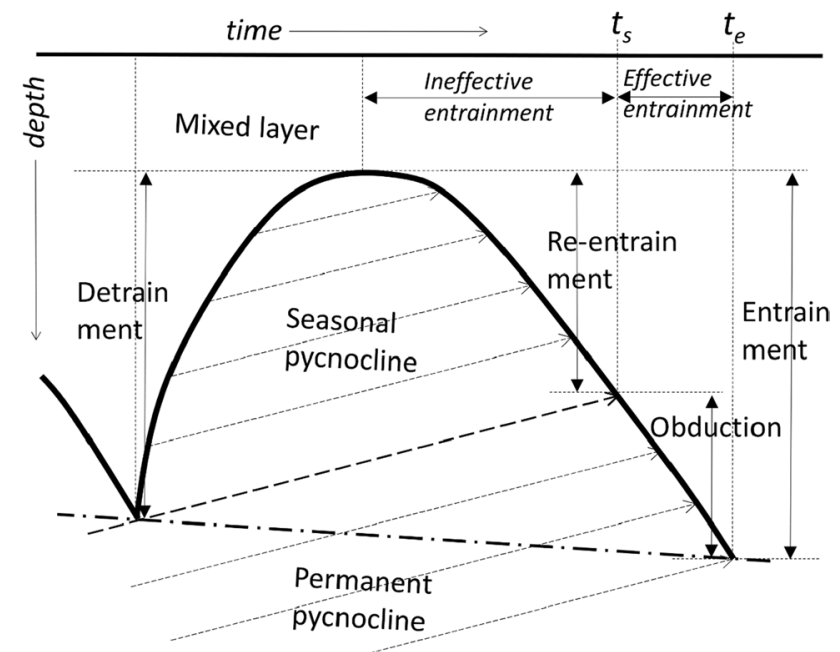

Fig. 1 Schematic picture of the obduction process (adapted from Fig. 3 of Qiu and Huang 1995). The solid curve depicts the seasonal cycle of the ML depth. Dotted arrows denote along-isopycnal, geostrophic flows. In the period before $t_{s}$ (Eq. (7)), a water parcel that was in the ML in the previous winter is entrained into the ML again. This is referred to as ineffective entrainment or re-entrainment in this paper. After $t_{s}$, permanent pycnocline water enters the ML, which is defined as obduction

for atmospheric circulations and air-sea interaction. The obduction is expected to be of relatively minor importance for air-sea interaction compared with the reemergence because the amount of water obducted from the permanent pycnocline will be smaller than that of re-entrained water. The obducted water, however, can occupy $20 \%$ or more of the water entrained into the ML in some regions and is never negligible for the ML temperature and salinity as shown in Sect. 3. The water imported from the permanent pycnocline to the ML can have an old memory of more than 1 year and transport anomalies of properties a long distance from an area where the water is subducted. Obduction and its impact on the ML properties is essential for long-term air-sea interaction research. Toyama et al. (2017), who examined the subduction and obduction rates of anthropogenic carbon using a biogeochemistry model, indicated that the median ocean interior travel time of obducting particles was generally less than 10 years and that the rapid renewal should suppress the air-sea exchange of carbon.

In this study the authors obtain global obduction and subduction rates with the Eulerian definition based on in situ observations, more than 10 years of Argo floats and ship data. This calculation enabled us to evaluate the contribution of obduction to the ML heat and salinity budgets and to trace water parcels below the ML. Section 2 provides explanations of the data and calculation method. Results are shown in Sect. 3. We pick up some areas where the effect of obducted water on the ML temperature or salinity is large as examples, and show seasonal or interannual variations of 
the ML budgets. Residence time and route of waters below the ML are also discussed in Sect. 3. In Sect. 4, we focus on recent interannual variations of obduction and subduction after 2013 in the mid and high latitudes of the Northern Hemisphere, especially the effects of the Pacific blob event, which is a prominent marine heatwave (e.g. Bond et al. 2015). Section 5 is a summary.

\section{Data and method}

\subsection{Data}

To investigate the global obduction and subduction rates, we use a monthly gridded dataset of temperature and salinity based on Argo float data (the Grid Point Value of the Monthly Objective Analysis: MOAA-GPV) (Hosoda et al. 2008). The used data for the MOAA-GPV are mainly obtained from Argo floats and vertically interpolated into selected standard pressure levels from 10 to 2000 dbar using the Akima spline (Argo 2020; Akima 1970). The spatial resolution of the dataset is $1^{\circ} \times 1^{\circ}$ horizontally in the latitudinal area within $61^{\circ} \mathrm{S}$ to $61^{\circ} \mathrm{N}$ except for the North Atlantic, where the northern boundary is $71^{\circ} \mathrm{N}$. The monthly dataset of temperature and salinity consists of gridded data into $1^{\circ} \times 1^{\circ}$ fields using the two-dimensional optimal interpolation method to be able to represent large-scale variability with long-term change. As accuracy and errors of the MOAA-GPV depend on weights of float data for each grid related to the number of profiles, the spatial distribution of Argo profiles in the North Pacific is not sufficient in 2003 or before (see Fig. 1 of Toyama et al. 2015); therefore, the data from 2001 to 2003 are not used in this study.

Monthly data are too sparse temporally to accurately classify entrained/detrained water into the obduction/subduction and re-entrainment components (Sect. 2.2.2); therefore, 1-day mean values obtained by linear interpolation from the monthly data are analyzed. Temperature and salinity profiles are vertically interpolated into a 10-dbar grid using Akima spline from the MOAA GPV data (Toyama et al. 2015). The MOAA GPV dataset has no data south of $61^{\circ} \mathrm{S}$ and north of $71^{\circ} \mathrm{N}$ (no data north of $61^{\circ} \mathrm{N}$ for the Pacific sector), and below $2000 \mathrm{~m}$. We need to note that water parcels that go across the southern or northern domain boundary, or subduct from or obduct in the ML of more than $2000 \mathrm{~m}$ cannot be considered in our calculation. The equatorial region in $5^{\circ}$ $\mathrm{S}-5^{\circ} \mathrm{N}$ is also excluded from the analysis.

Numerical simulations have shown that mesoscale eddies enhance the annual obduction and subduction rates by nearly a factor of two or more (e.g. Nishikawa et al. 2010; Liu et al. 2016). Using the MOAA GPV dataset makes it impossible to detect the effect of eddies. Besides the eddies, the western boundary currents are blurred in this dataset. Estimating the obduction and subduction rates without eddies is, however, still meaningful. While it is impossible to accurately consider the effect of eddies and the narrow currents over a wide basin by in situ observations only, observation-based evaluation of the ocean circulation is indispensable as a benchmark to assess the reliability of numerical models. One should note that the results shown in this paper do not include the effect of eddies and filtering to smooth out eddies needs to be applied to model data when verifying the model with the observation-based estimations.

Surface heat, freshwater, and momentum fluxes are obtained from a globe atmospheric reanalysis dataset, the European Centre for Medium-Range Weather Forecast (ECMWF) reanalysis interim version (ERA-interim) (Berrisford et al. 2011). The original grid interval is approximately $0.70^{\circ}$ (nearly $80 \mathrm{~km}$ ), and monthly data are used with temporal interpolation in this study.

\subsection{Methods}

\subsubsection{Mixed-layer budget}

The advection-diffusion equation of temperature for each water column is as follows:

$$
\begin{array}{r}
\int_{-D}^{0} \frac{\partial T}{\partial t} \mathrm{~d} z=-\int_{-D}^{0}\left(\boldsymbol{u} \cdot \nabla_{\boldsymbol{h}} T+w \frac{\partial T}{\partial z}\right) \mathrm{d} z+\frac{Q}{c_{\mathrm{p}} \rho} \\
+\int_{-D}^{0}\left[\frac{\partial}{\partial x}\left(K_{x} \frac{\partial T}{\partial x}\right)+\frac{\partial}{\partial y}\left(K_{y} \frac{\partial T}{\partial y}\right)\right] \mathrm{d} z-\left[K_{z}\left(\frac{\partial T}{\partial z}\right)\right]_{z=-D},
\end{array}
$$

where $T, \boldsymbol{u}$, and $w$ are temperature, horizontal, and vertical velocity, respectively. $D, Q, c_{\mathrm{p}}$, and $\rho$ are ML depth, net surface heat flux, specific heat at a constant pressure, and the density of ML water. $K=\left(K_{x}, K_{y}, K_{z}\right)$ is a vector that consists of horizontal and vertical eddy diffusion coefficients. Using the continuity equation, the ML heat budget can be expressed as (Cronin et al. 2013; Katsura et al. 2013) follows:

$$
\begin{array}{r}
\frac{\partial T_{m}}{\partial t}=-\boldsymbol{u}_{g} \cdot \nabla_{\boldsymbol{h}} T_{m}-\boldsymbol{u}_{\boldsymbol{E}} \cdot \nabla_{\boldsymbol{h}} T_{m}+\frac{Q}{D c_{\mathrm{p}} \rho}-\frac{\left(T_{m}-T_{-D}\right) W_{\mathrm{e}}}{D}+R_{t} \\
R_{t}=-\frac{1}{D} \nabla_{\boldsymbol{h}} \cdot \int_{-D}^{0} \boldsymbol{u}^{\prime} T^{\prime} \mathrm{d} z+\frac{1}{D} \int_{-D}^{0}\left[\frac{\partial}{\partial x}\left(K_{x} \frac{\partial T}{\partial x}\right)+\frac{\partial}{\partial y}\left(K_{y} \frac{\partial T}{\partial y}\right)\right] \mathrm{d} z \\
-\frac{1}{D}\left[K_{z}\left(\frac{\partial T}{\partial z}\right)\right]_{z=-D}
\end{array}
$$


$\boldsymbol{u}_{\boldsymbol{E}}=\frac{1}{\rho f D}\left(\tau^{y},-\tau^{x}\right)$

$W_{\mathrm{e}}=\left\{\begin{array}{c}\frac{\partial D}{\partial t}+\nabla_{\boldsymbol{h}} \cdot\left(D \boldsymbol{u}_{\boldsymbol{m}}\right), \frac{\partial D}{\partial t} \geq-\nabla_{\boldsymbol{h}} \cdot\left(D \boldsymbol{u}_{\boldsymbol{m}}\right) \\ 0, \frac{\partial D}{\partial t}<-\nabla_{\boldsymbol{h}} \cdot\left(D \boldsymbol{u}_{\boldsymbol{m}}\right)\end{array}\right.$,

where $W_{\mathrm{e}}$ is the entrainment velocity. $T^{\prime}$ and $\boldsymbol{u}^{\prime}$ are the deviations of temperature and horizontal velocity from the averages within the ML, $T_{m}$, and $\boldsymbol{u}_{\boldsymbol{m}}$, respectively. $T_{-D}$ is the temperature just below the base of the ML, and the value $20 \mathrm{~m}$ below the base is used (e.g. Ren and Riser 2009; Katsura et al. 2013) in our budget analysis. $\boldsymbol{u}_{g}$ and $\boldsymbol{u}_{\boldsymbol{E}}$ are geostrophic and Ekman velocities averaged within the ML, and the sum of them is equal to $\boldsymbol{u}_{\boldsymbol{m}} f, \tau_{x}$, and $\tau_{y}$ are the Coriolis parameter, zonal, and meridional wind stresses. $D$ is determined as the depth at which the potential density difference from a near-surface value at $10-\mathrm{m}$ depth exceeds $+0.125 \mathrm{~kg} \mathrm{~m}^{-3}$ (Levitus 1982; Toyama et al. 2015). The diffusion term cannot be calculated from the MOAA GPV data and is included in the residual term $R_{t}$. The first term on the right-hand side of Eq. (3) is derived from the advection term of Eq. (1) and is negligible when the temperature is almost vertically homogeneous. Similarly, the salinity budget equation of the ML is also derived:

$\frac{\partial S_{m}}{\partial t}=-\boldsymbol{u}_{g} \cdot \nabla_{\boldsymbol{h}} S_{m}-\boldsymbol{u}_{\boldsymbol{E}} \cdot \nabla_{\boldsymbol{h}} S_{m}+\frac{(E-P) S_{m}}{D}-\frac{\left(S_{m}-S_{-D}\right) W_{\mathrm{e}}}{D}+R_{s}$,

where $S_{m}, S_{-D}, E, P$, and $R_{s}$ are the mean salinity within the ML, the salinity just below the base of the ML, evaporation, precipitation, and the residual term of salinity. In this paper, the horizontal advection terms are not discussed and they are added to the residual term in the following budget analyses.

\subsubsection{Annual obduction and subduction rates with the Eulerian definition}

The Lagrangian definition has been often used to estimate the annual obduction and subduction rates conventionally (e.g. Qiu and Huang 1995; Toyama et al. 2015). However, it is difficult to directly associate the obduction rate with the ML budget analysis by the Lagrangian definition. Hence the Eulerian definition is applied in this study. The annual obduction rate $O_{\text {ann }}$ is defined as:

$O_{\mathrm{ann}}=\frac{1}{t_{\mathrm{a}}} \int_{t_{\mathrm{s}}}^{t_{\mathrm{e}}} o_{\mathrm{i}} \mathrm{d} t$

$o_{\mathrm{i}}=\frac{\partial D}{\partial t}+\boldsymbol{u}_{\boldsymbol{m b}} \cdot \nabla_{\boldsymbol{h}} D+w_{m b}=\frac{\partial D}{\partial t}+\nabla_{\boldsymbol{h}} \cdot\left(D \boldsymbol{u}_{\boldsymbol{m}}\right)$, where $t_{\mathrm{a}}$ is the time of the average, taken as 1 year here. $o_{\mathrm{i}}$ is the instantaneous obduction rate (Cushman-Roisin 1987; Liu et al. 2011), and $\boldsymbol{u}_{\boldsymbol{m}}$ and $w_{m b}$ are horizontal and vertical velocity at the base of the ML. $t_{\mathrm{s}}$ and $t_{\mathrm{e}}$ are times when effective entrainment starts and ends (Fig. 1). The "effective entrainment" means that a water parcel that was below the ML in the previous winter is entrained. We determine whether each entrained water parcel is effective or ineffective by tracing a trajectory on an isopycnal surface of a parcel released at the base of the ML backward at every time step (1 day). If the entrained water was below the ML and not in any land grid throughout 1 year, it is regarded as effective entrainment, that is, obduction. By definition, $o_{\mathrm{i}}$ in Eq. (8) should be positive, just the same as $W_{\mathrm{e}}$ in Eq. (5). We can divide the entrainment term in Eq. (2) into the obduction and re-entrainment components based on the isopycnal backward trajectory:

$$
\begin{aligned}
-\frac{\left(T_{m}-T_{-D}\right) W_{\mathrm{e}}}{D}= & {\left[-\frac{\left(T_{m}-T_{-D}\right) W_{\mathrm{e}}}{D}\right]_{\text {obduction }} } \\
& +\left[-\frac{\left(T_{m}-T_{-D}\right) W_{\mathrm{e}}}{D}\right]_{\text {re-entrainment }} .
\end{aligned}
$$

In the same way, a detrained water parcel can be sorted into the subduction and re-entrainment components (Fig. 1). The isopycnal velocities, which are 5-day means to save computation time, are obtained from the pressure anomaly stream function defined by Zhang and Hogg (1992) on an isopycnal surface at 0.1 potential density interval.

\section{Results}

\subsection{Mean obduction and subduction rates}

First of all, the annual maximum depth of the ML is checked (Fig. 2). The general feature of the maximum depth is consistent with previous studies (e.g. Karstensen and Quadfasel 2002; Toyama et al. 2015). In the Southern Hemisphere, the regions where the ML was deeper than $200 \mathrm{~m}$ were along the northern flank of the Circumpolar Current. Most of the ML trough lay between 26.5 and $27.0 \sigma_{\theta}$ in the Southern Hemisphere. The maximum ML depth along the circumpolar trough was about $200 \mathrm{~m}$ in the western Indian Ocean, where the depth and density were smaller than that in the eastern side. The climatological maximum depth in the zonal regions south of Australia reached $700 \mathrm{~m}$ or more. The depth along the trough was relatively shallow in the South Atlantic, but exceeded $200 \mathrm{~m}$. In the northern North Atlantic south off Greenland between 30 and $60^{\circ} \mathrm{W}$, the late-winter ML depth reached more than $1000 \mathrm{~m}$, and exceeded $2000 \mathrm{~m}$ in the Labrador Sea, where the standard Argo floats and 

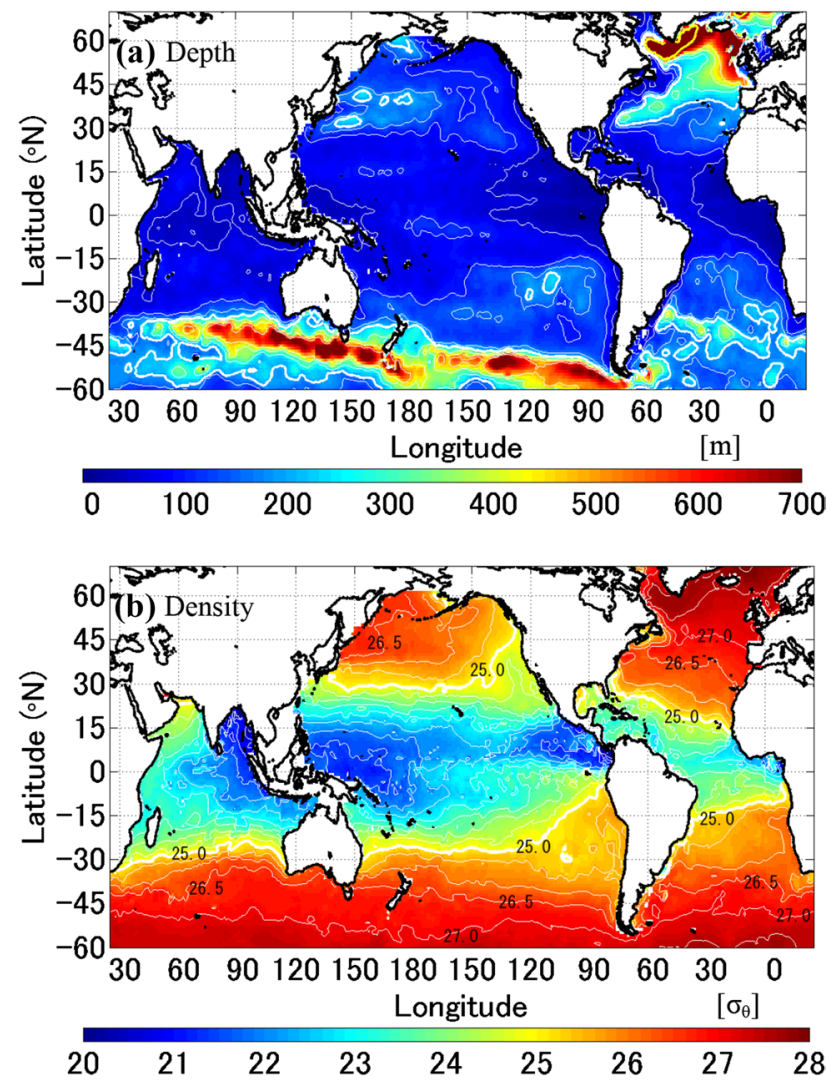

Fig. 2 a Annual maximum ML depth and b density derived from monthly climatologies from 2004 to 2018 . In a, contour intervals are $50 \mathrm{~m}$ from $50 \mathrm{~m}$ to $200 \mathrm{~m}$, and $100 \mathrm{~m}$ from $200 \mathrm{~m}$. The white and yellow bold contours indicate $200 \mathrm{~m}$ and $1000 \mathrm{~m}$, respectively. In b, contour intervals are 0.5 and the bold contour indicates 25.0

MOAA GPV dataset cannot detect the bottom of the ML in late winter. The maximum ML was relatively shallow in the North Pacific. It exceeded $200 \mathrm{~m}$ only in the southwestern Bering Sea and limited areas within the Kuroshio recirculation region and along the southern rim of the subarctic gyre. The density surpassed $26.5 \sigma_{\theta}$ in the Oyashio region and the western Bering Sea only.

The spatial patterns of the annual mean obduction and subduction rates with the Eulerian definition (Fig. 3) are basically close to those estimated with the Lagrangian definition (e.g. Qiu and Huang 1995; Karstensen and Quadfasel 2002; Liu and Huang 2012). The obduction/subduction rates were large along the circumpolar ML trough in the Southern Ocean, but the subduction rate was smaller in south of the trough compared with the previous studies. One of the reasons is that water parcels cannot be tracked south of $61^{\circ} \mathrm{S}$. As mentioned in Sect. 2.1, underestimation of the obduction and subduction rates is inevitable near the southern/northern domain boundaries, the equatorial band, and around the Labrador Sea (areas surrounded with magenta lines in Fig. 3). The ratio of the obduction rate to the total entrainment rate
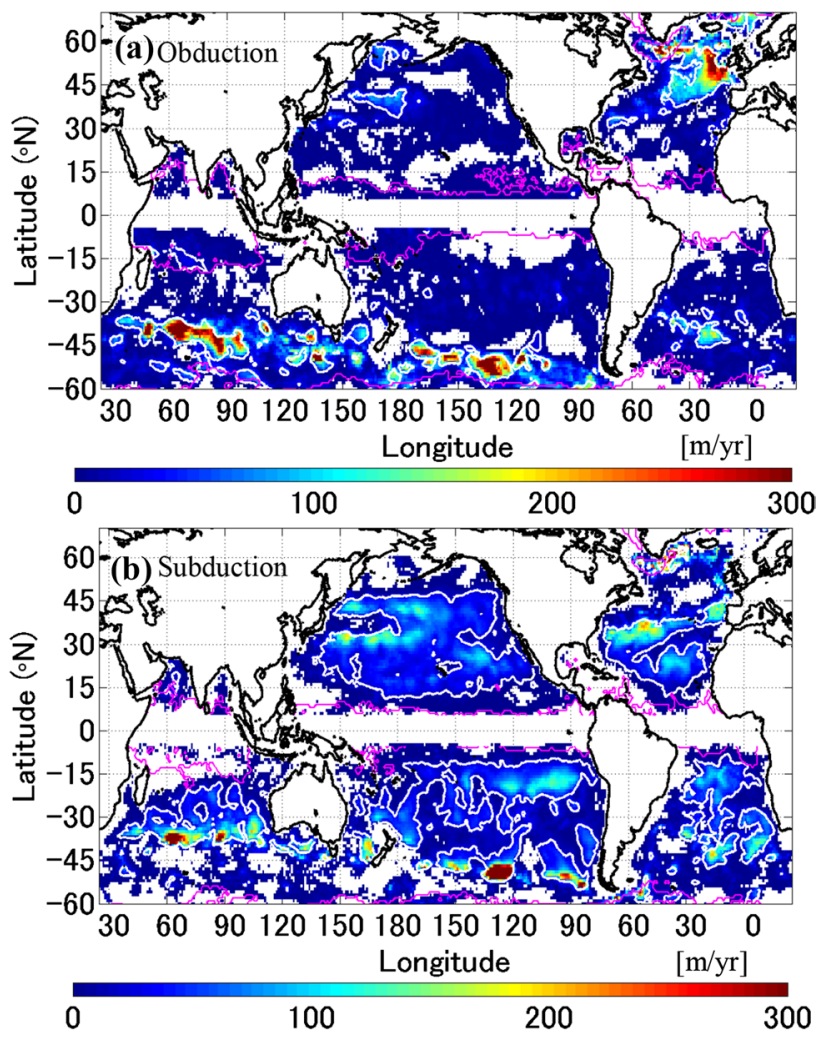

Fig. 3 a Annual obduction and $\mathbf{b}$ subduction rates averaged from 2005 to 2018. Regions enclosed with white lines indicate where obducted (subducted) water accounts for $20 \%$ or more of entrained (detrained) water. Magenta contours denote areas where the obduction or subduction rate is underestimated due to its closeness to the domain boundary or the $5^{\circ} \mathrm{S} / \mathrm{N}$ lines or the ML deeper than $2000 \mathrm{~m}$. White grids mean no subduction/obduction

exceeded $20 \%$ where the obduction rate was large, and these regions accounted for $10.5 \%$ of the whole domain. The regions with the subduction-to-detrainment ratio of more than $20 \%$ were $25.2 \%$ of the domain.

We check the consistency of our calculation with previous studies for the North Pacific. The temporal variations of the obduction and subduction rates in the North Pacific, which show a striking increase in 2010, are consistent with those shown by Toyama et al. (2015), although the temporal mean of obduction is smaller by about $0.5 \mathrm{~Sv}$ and that of subduction is larger by about $7 \mathrm{~Sv}$ (Fig. 4). Toyama et al. (2015) indicated the correspondence between the subduction rate within this region and the Pacific Decadal Oscillation (PDO) index. The PDO index became positive and large from 2014 to 2017 (not shown). Increases of the obduction rate in 2014 and 2016 might be partly related with the PDO, but the subduction rate did not correspond to the PDO index after 2013.

One possible reason for our subduction rate being larger than the previous studies in the North Pacific (Qiu and Huang 1995; Suga et al. 2008; Toyama et al. 2015) is smallscale variations that are not completely smoothed out in the 


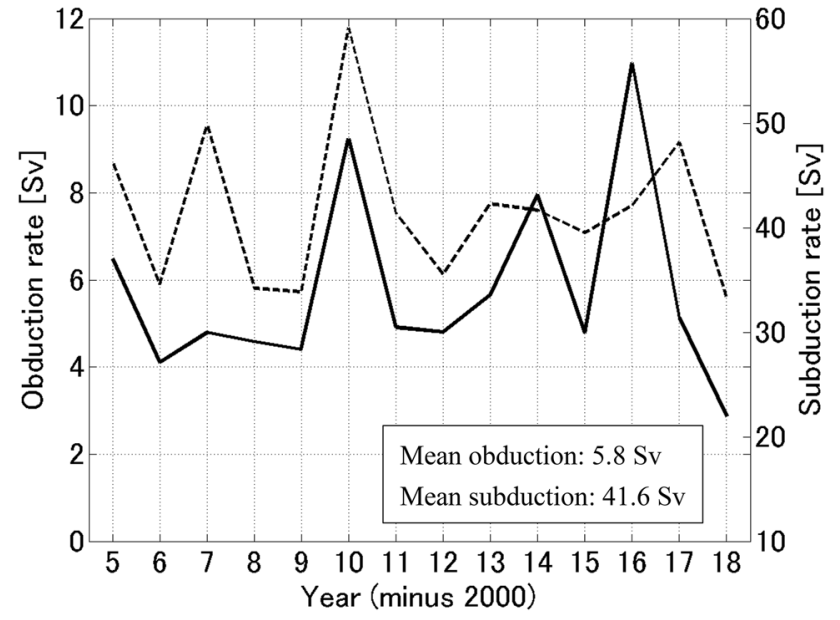

Fig. 4 Annual obduction (solid line) and subduction (dashed line) rates in the region of $15^{\circ}-45^{\circ} \mathrm{N}, 135^{\circ} \mathrm{E}-110^{\circ} \mathrm{W}$

gridded dataset. For the lateral induction, we see only the differences of the horizontal position and ML depth between two winters for each water column in the Lagrangian definition. On the other hand, in the Eulerian definition, a small part detrained from the ML at every time step is tracked on an isopycnal surface for 1 year, and we integrate the parcels not being entrained into the ML. For example, if the ML depth has double peaks at a grid within 1 year, the Eulerian definition will produce larger subduction rate than the Lagrangian definition, and the Eulerian definition needs to be adopted (cf. Liu et al. 2011). Furthermore, while the ML depth in the formation areas of the North Pacific subtropical and central mode waters are less than $250 \mathrm{~m}$ (Fig. 2a), these mode waters spread to around $300 \mathrm{~m}$ depth or deeper (e.g. Qiu et al. 2006; Oka et al. 2020), which is captured in the Eulerian definition. The vertical shift of water column is considered solely by the vertical pumping term in the Lagrangian definition, but the vertical pumping rate is a few tens of meters per year in the North Pacific (Qiu and

Table 1 Obduction and subduction rates averaged from 2005 to 2018 (Sv)

\begin{tabular}{llrrrr}
\hline & Hemisphere & Indian & Pacific & Atlantic & Sum \\
\hline Obduction & Northern & 0.1 & 8.7 & 30.1 & 38.9 \\
& Southern* & 46.0 & 40.0 & 10.3 & 96.3 \\
& Sum & 46.1 & 48.7 & 40.4 & 135.2 \\
Subduction & Northern & 0.7 & 46.1 & 31.4 & 78.2 \\
& Southern* & 31.0 & 59.2 & 26.0 & 116.2 \\
& Sum & 31.7 & 105.3 & 57.4 & 194.4 \\
\hline
\end{tabular}

*The zonal boundaries between the Atlantic, Indian, and Pacific Oceans in the Southern Hemisphere are $30^{\circ} \mathrm{E}, 145^{\circ} \mathrm{E}$, and $70^{\circ} \mathrm{W}$, respectively (Liu and Huang 2012)
Huang 1995; Suga et al. 2008) and is not large enough to explain the vertical displacement of the mode waters.

The obduction and subduction rates integrated for the global oceans are summarized in Table 1. Naturally, these values are much smaller compared with those of Liu and Huang (2012), who used an eddy-permitting reanalysis dataset that covers the whole globe. Our subduction rates in the Southern Hemisphere are relatively close to those of Karstensen and Quadfasel (2002).

\subsection{Mixed-layer cooling/salinizing by obducted water}

Cooling or salinizing rate of the ML due to the obduction process is part of the entrainment term as expressed in Eq. (9). Their spatial patterns basically reflect that of the obduction rate (Figs. 3a, 5). The contribution of obduction was smaller than $\pm 0.1 \mathrm{~K} / \mathrm{yr}$ over most of the regions, but exceeded $-0.5 \mathrm{~K} / \mathrm{yr}$ in places around the Circumpolar Current, in the northeastern tropical Pacific, the southwestern tropical Indian Ocean, and the northeastern North Atlantic (Fig. 5a), where the ratio of the obduction cooling
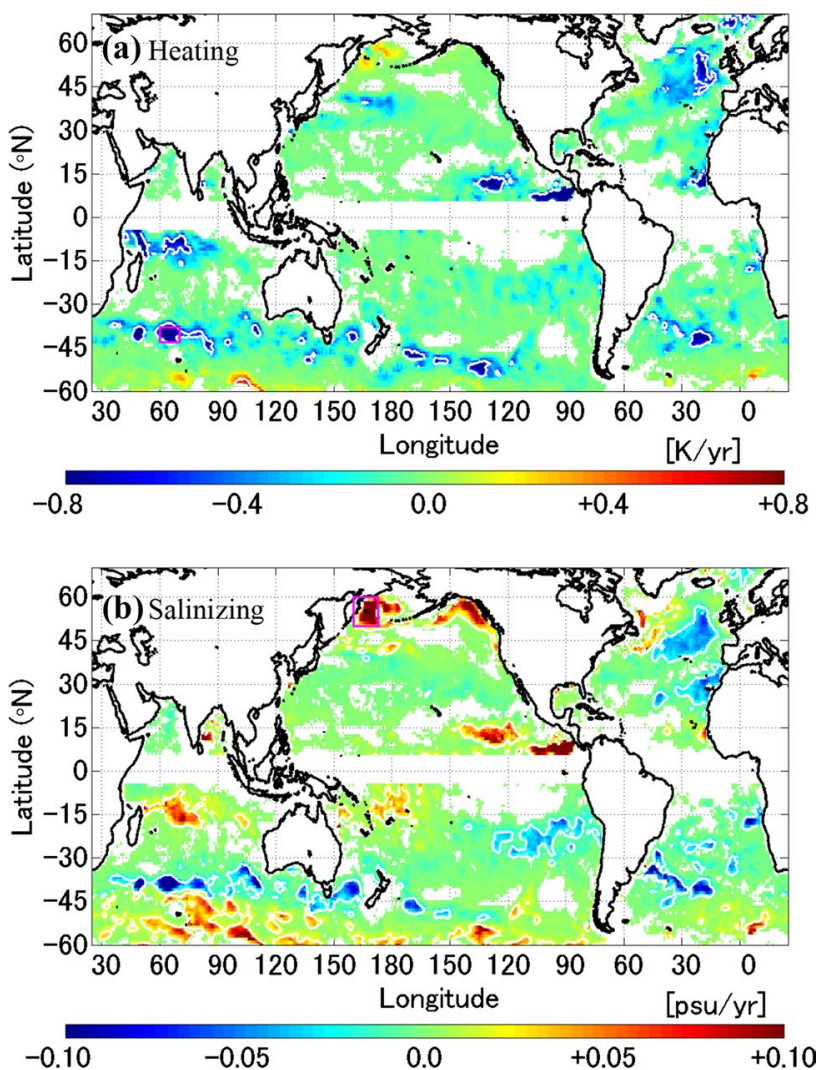

Fig. 5 a Heating and $\mathbf{b}$ salinizing rates of the ML by obducted water. The white contour indicates $\pm 0.5 \mathrm{~K} / \mathrm{yr}$ in (a) and $\pm 0.02 \mathrm{psu} / \mathrm{yr}$ in (b). The magenta rectangles in (a) and (b) show the regions where seasonal cycles of heat and salinity are examined in Fig. 6 
component to the total entrainment cooling term reached $20 \%$ or more. In the latitudes south of $50^{\circ} \mathrm{S}$ and north of $50^{\circ} \mathrm{N}$ in the North Pacific, the obduction process is related with heating due to the dichothermal structure. The salinity change rate due to obduction exceeded $\pm 0.02 \mathrm{psu} / \mathrm{yr}$ where the obduction cooling was large (Fig. 5b). The salinizing rate was also noticeable in the subarctic North Pacific and the eastern South Pacific. Basically the entrainment causes freshening in the mid latitudes and salinizing in the tropics and high latitudes. The salinization by obduction was especially large in the southwestern Bering Sea and the Gulf of Alaska, where the cooling was not very large.

Examples of the mean seasonal cycles of the ML budgets are shown in Fig. 6. Basically surface flux was dominant
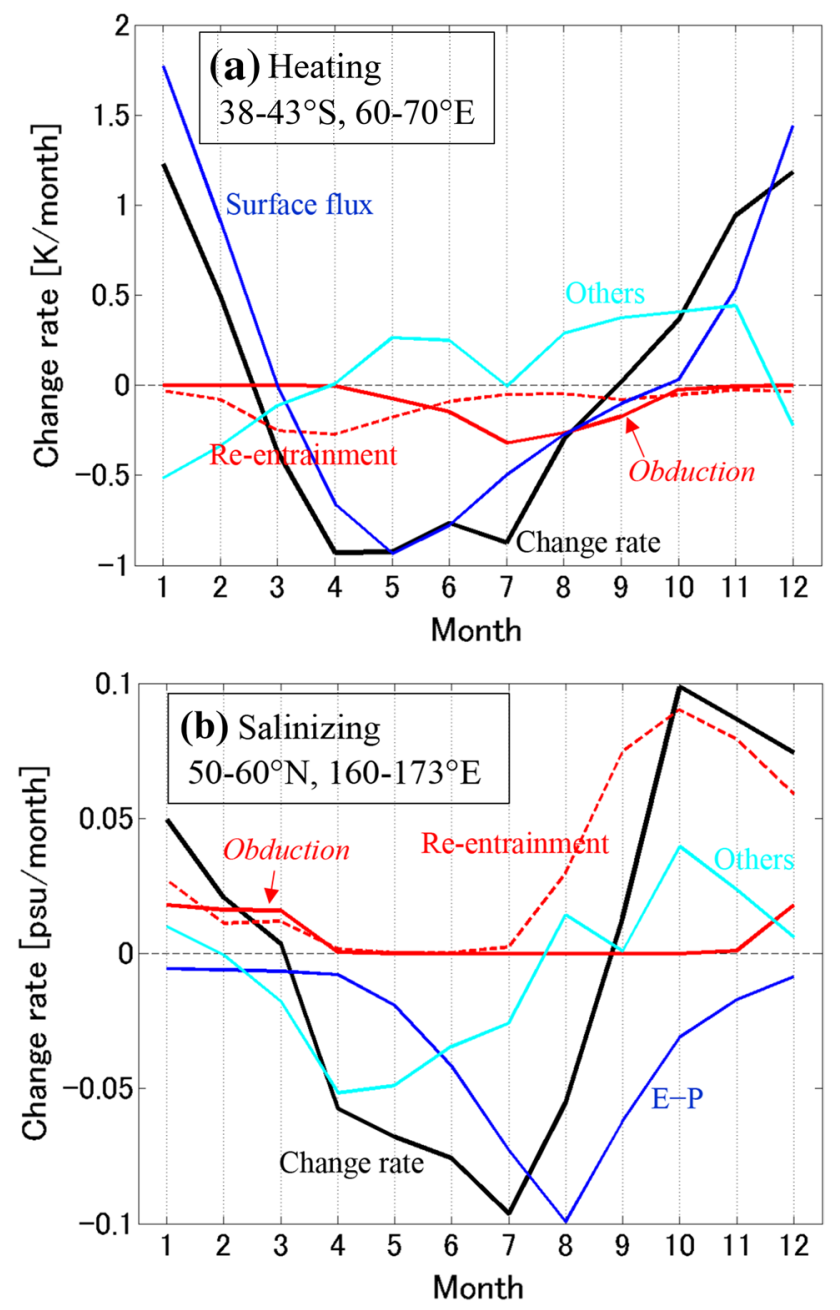

Fig. 6 Examples of mean seasonal cycle of ML budget. a Heat budget in $38^{\circ}-43^{\circ} \mathrm{S}, 60^{\circ}-70^{\circ} \mathrm{E}$ (box in Fig. $4 \mathrm{a}$ ), and b salinity budget in $50^{\circ}-60^{\circ} \mathrm{N}, 160^{\circ}-173^{\circ} \mathrm{E}$ (box in Fig. $4 \mathrm{~b}$ ). Change rate of temperature (salinity), obduction heating (salinizing), re-entrainment heating (salinizing), surface flux are denoted by the black solid, red solid, red dashed, and blue solid lines, respectively. The cyan solid line indicates the sum of Ekman advection, geostrophic advection, and residual term in both temperature and salinity budgets. Cooling due to entrainment began from late summer, and the contribution of obducted water became larger in winter in the area of $38^{\circ}-43^{\circ} \mathrm{S}, 60^{\circ}-70^{\circ} \mathrm{E}$ (Fig. 6a). The total cooling by the obduction component was close to that of the re-entrainment for this area. For salinity in the southwestern Bering Sea, entrainment started salinizing the ML from late summer and became dominant in autumn and winter (Fig. 6b). The effect of obducted water appeared in December and became larger than the re-entrainment component in late winter. Although the contribution of the re-entrainment component was much larger in total, the obduction component played an important role in wintertime salinity. In the regions such as the southwestern Bering Sea, the northern North Atlantic, and the mid-latitude Indian Ocean, water in the main pycnoline started being entrained into the ML in December or earlier (Fig. 7a). It is reasonable that the onset of obdcution, $t_{\mathrm{s}}$ in Eq. (7), tended to be earlier and the duration of obduction tended to be long where the obduction effect was large (Fig. 7b) since the formation of deeper ML needs
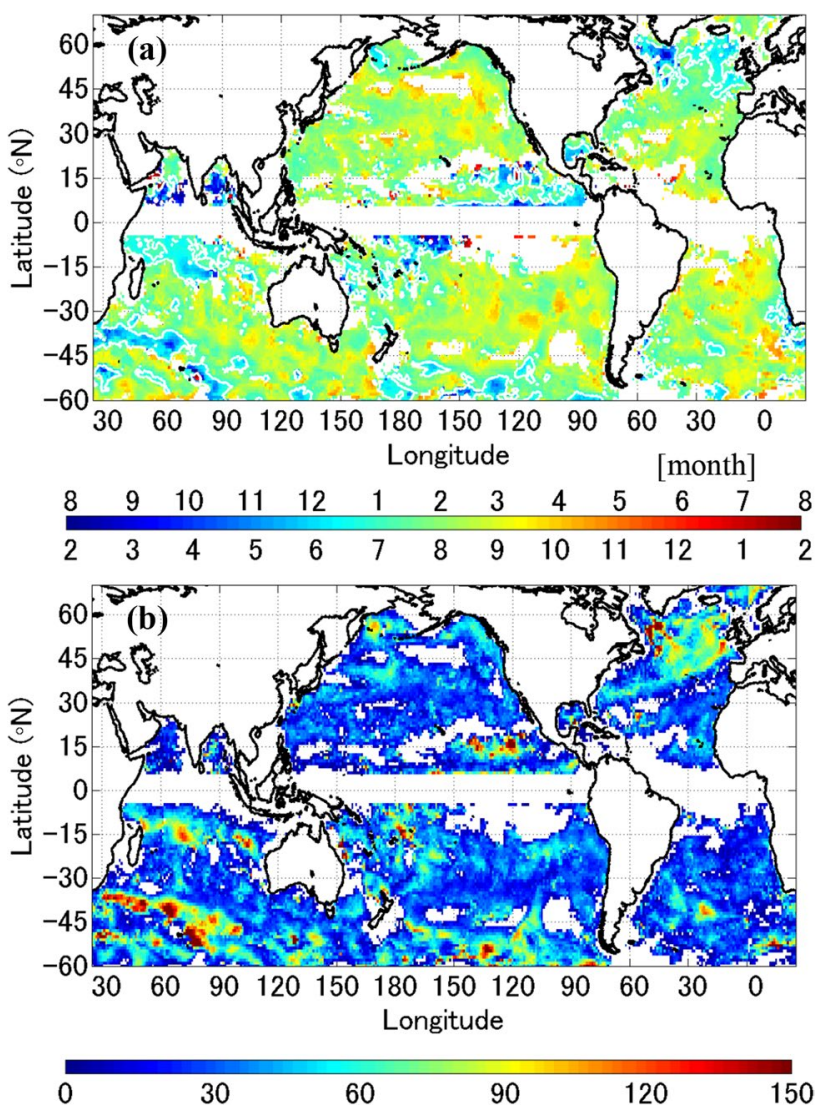

Fig. 7 a Climatology of the mean date (in month) when effective entrainment starts. Color varies from August to August in the Northern Hemisphere, and from February to February in the Southern Hemisphere (see the color bar). The white contours indicate January 1st for the Northern Hemisphere, and July 1st for the Southern Hemisphere. b Climatology of the duration of obduction $\left(t_{e}-t_{s}\right)$ 
longer time. Marchall et al. (1993) indicated that the effective period in which fluid was irreversibly entrained from the main thermocline into the ML, namely obduction, was 2-4 months in the subpolar gyre in the North Atlantic (their Fig. 6). Our result is not contradictory to their indication, although the duration in the North Atlantic is shorter in our analysis.

The effect of obduction to interannual variations of temperature and salinity is then examined. We show the ratio of the variance of the obduction cooling/salinizing term to that of the ML temperature/salinity change rate through the cold season to assess the contribution of the obduction term. The ratio for the temperature is:

$\frac{\operatorname{Var}\left(\int_{t_{0}}^{t_{1}}\left[-\frac{\left(T_{m}-T_{-D}\right) W_{e}}{D}\right]_{\text {obduction }} \mathrm{d} t\right)}{\operatorname{Var}\left(\int_{t_{0}}^{t_{1}} \frac{\partial T_{m}}{\partial t} \mathrm{~d} t\right)}$,

where $\operatorname{Var}(x)$ means the variance of $x . t_{0}$ and $t_{1}$ are the start (October in the Northern Hemisphere, April in the Southern Hemisphere) and the end (April in the Northern
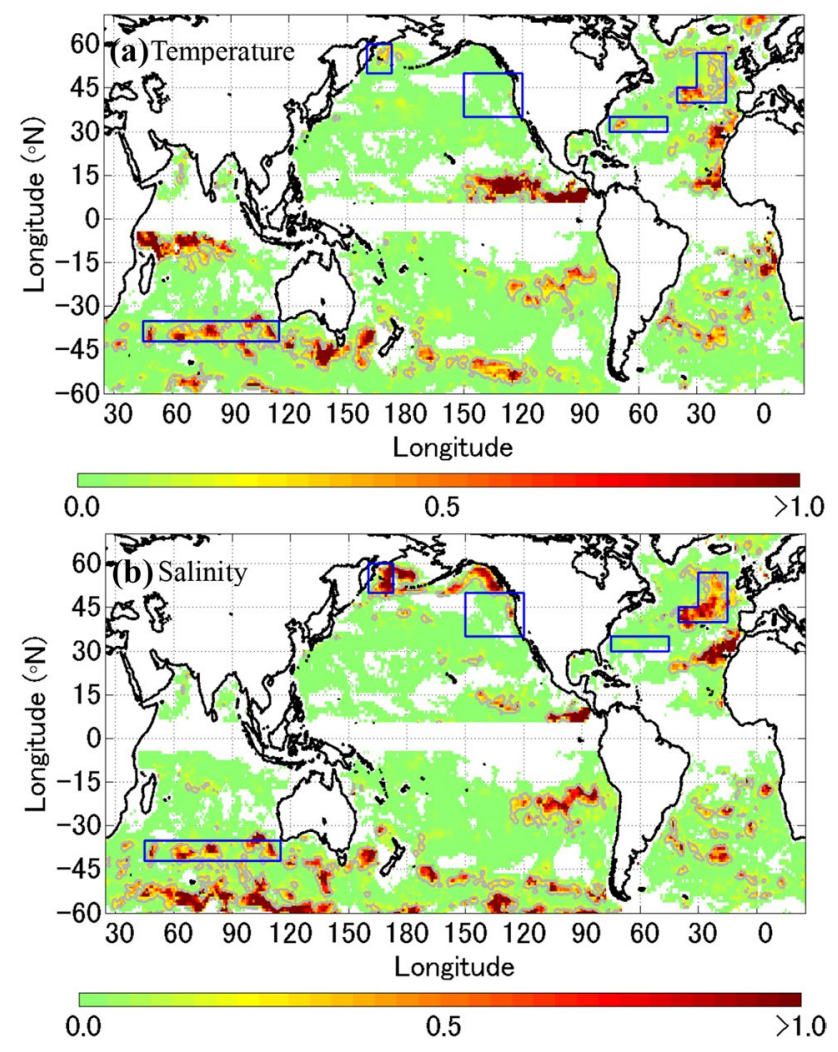

Fig. 8 a Ratio of the variance of the obduction heating term to that of the temperature change rate in the cold season (Eq. (10)). b Same as (a) but for salinity. The gray contours indicate 0.2 . The blue rectangles show the regions where interannual changes of heat and salinity are examined in Figs. 9, 12, 16, 18 and 19
Hemisphere, October in the Southern Hemisphere) of the cold season, respectively.
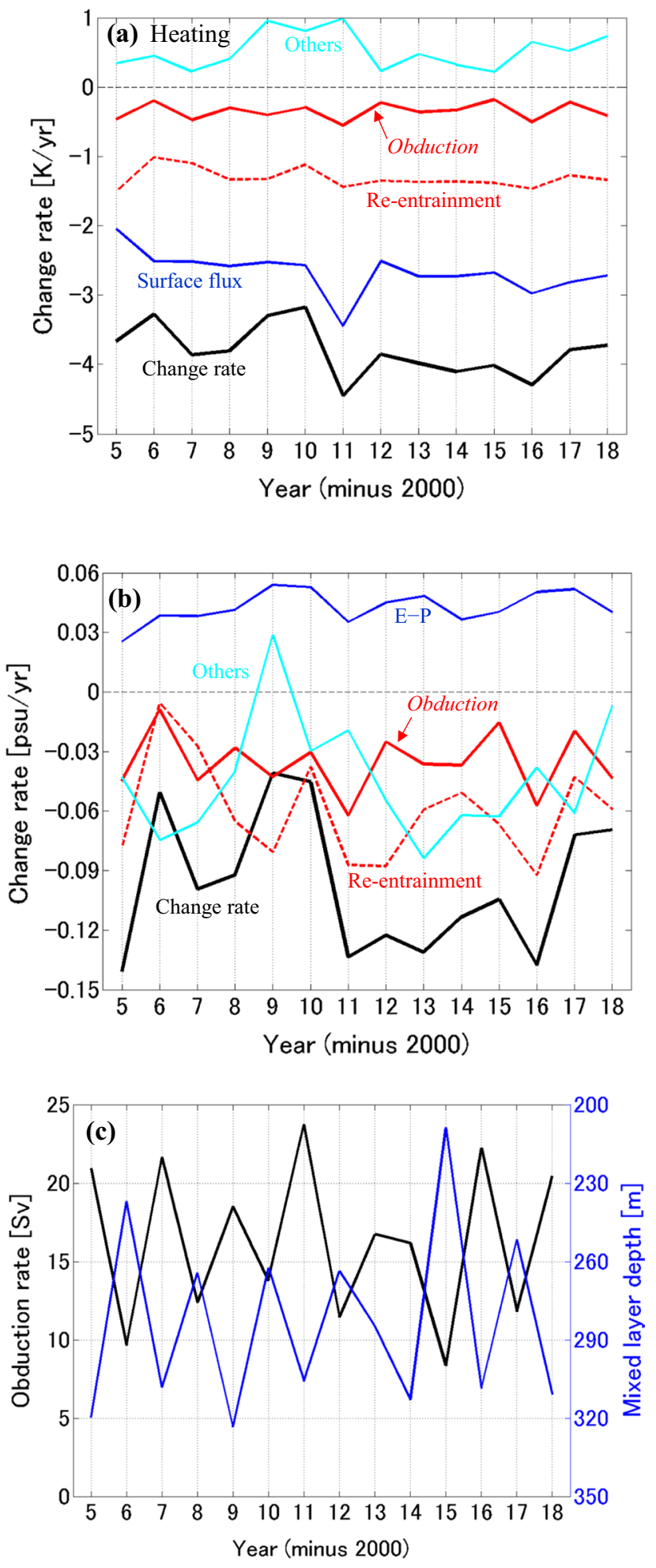

Fig. 9 a Change rate of the ML temperature and its components in the mid-latitude Indian Ocean $\left(35^{\circ}-42^{\circ} \mathrm{S}, 45^{\circ}-115^{\circ} \mathrm{E}\right)$. b As in (a), but for salinity. c Annual obduction rate and depth of the wintertime ML (July-September) in this region 
Obviously, the spatial distribution of the ratio (Fig. 8) almost mirrored that of the obduction cooling/salinizing term in Fig. 5. In the high and mid latitudes, the effect on temperature was relatively small compared with that on salinity, probably because surface heat flux was more effective on the ML budget. On the other hand, the obduction process affected the ML temperature more than the salinity in the northeastern tropical Pacific and the southwestern tropical Indian Ocean. Although it might be associated with the El Nino or Indian Ocean Dipole event, we do not focus it in this paper since water parcels coming from the zone of $5^{\circ}$ $\mathrm{S}$ to $5^{\circ} \mathrm{N}$ are not counted in the obduction rate and the rate near the equator will be less accurate (Fig. 3).

For the mid latitude in the Indian Ocean, where the variability of obduction was large (Fig. 8), the interannual variation of the ML temperature change rate was determined mainly by surface heat flux, but the variation of the obduction heating term also corresponded to the ML change rate (Fig. 9a). For salinity, both the obduction and re-entrainment terms greatly contributed to the ML change rate (Fig. 9b). The obduction rate and heating/salinizing terms tended to be small when the ML was shallow (Fig. 9c). The variation of salinity in the southwestern Bering Sea, which is one of
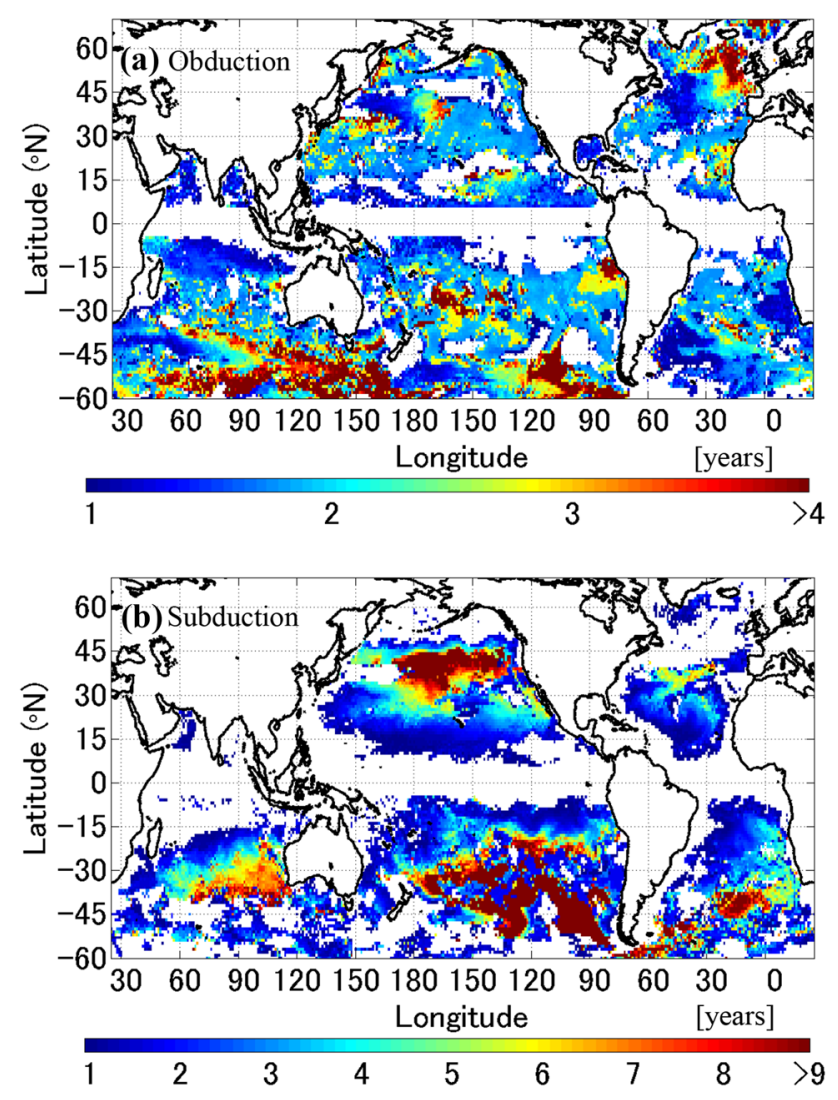

Fig. 10 a Median residence time below the ML of obducted water parcels from 2009 to 2018. b As in (a), but for subducted water parcels from 2005 to 2010 the most important areas from the viewpoint of obduction (Fig. 8b), is focused on in Sect. 4.1.

\subsection{Residence time and route within the ocean interior}

Residence time of obducted or subducted waters within the ocean interior is estimated by tracking them for more than 1 year (Fig. 10). Note that this estimation is based on geostrophic velocity on an isopycnal surface only, and the effects of diffusion and eddies are not considered. Properties of a water mass would dissipate and its trajectory would deviate from the actual one gradually during a long tracking period. In fact, the residence time shown in Fig. 10 was much shorter compared with previous studies with threedimensional model trajectory (Blanke et al. 2002; Toyama et al. 2017). It will be useful, however, to approximately see where aged waters tend to appear in the ML or where aged waters originate. The spatial distribution of the travel
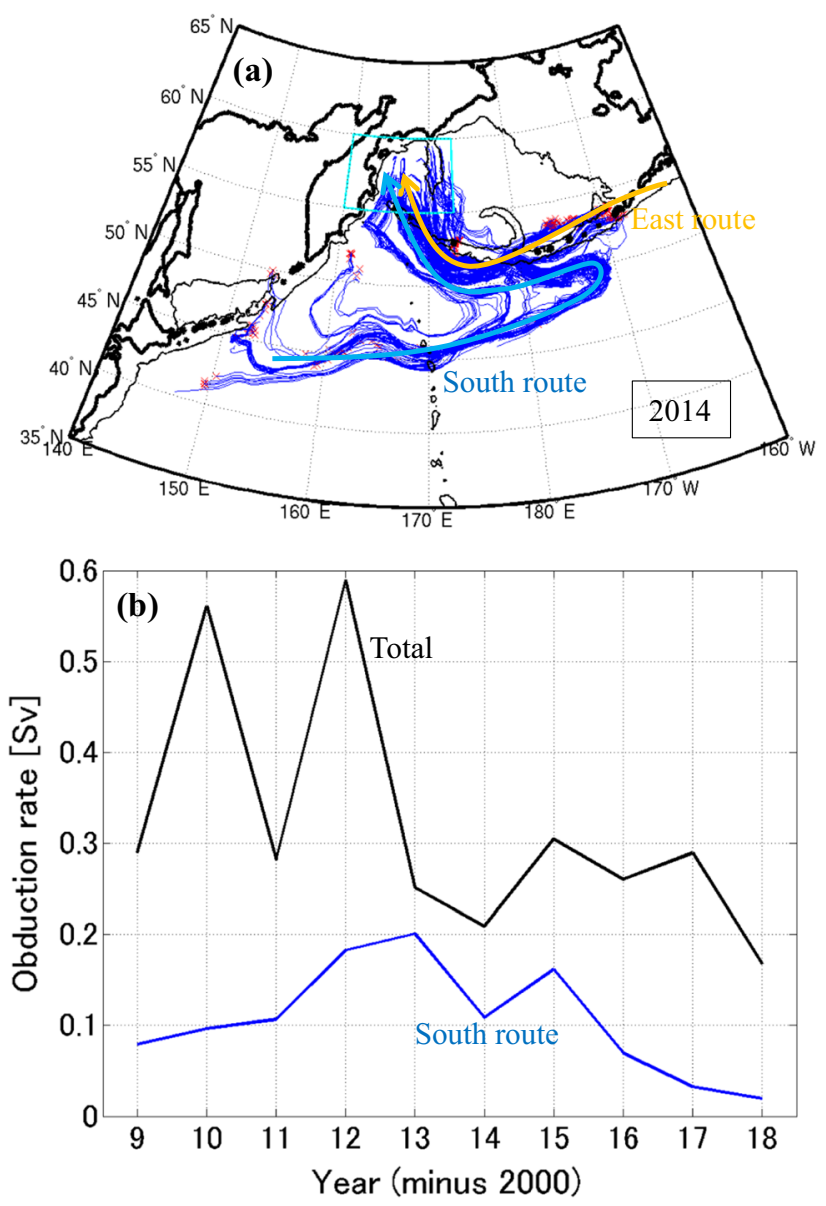

Fig. 11 a 4-Year trajectories of water parcels obducted within the area of $55^{\circ}-60^{\circ} \mathrm{N}, 160^{\circ}-173^{\circ} \mathrm{E}$ (enclosed by cyan lines) in the winter of 2014. Red marks indicate positions where water parcels were 4 year before, or subducted, or encountered land. b Total obduction rate within the cyan box (black), and obduction rate by water parcels followed the South route (blue) 

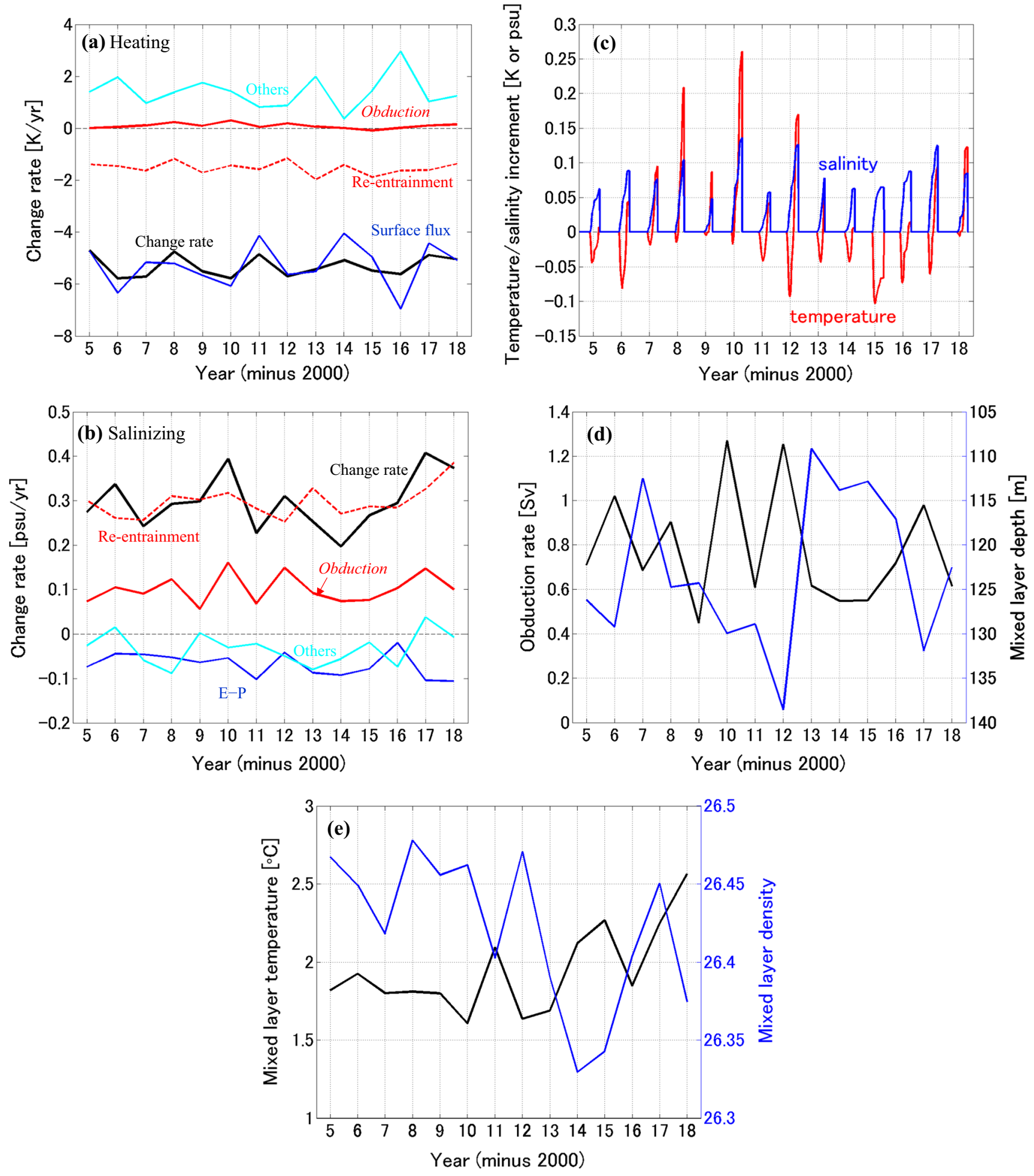

Fig. 12 Change rate of the ML a temperature, and $\mathbf{b}$ salinity and their components in the southwestern Bering Sea $\left(50^{\circ}-60^{\circ} \mathrm{N}, 160^{\circ}-173^{\circ}\right.$ E). c Increments of ML temperature and salinity by obduction. d

time was qualitatively close to Toyama et al. (2017) (their Fig. 8). The waters subducted in $30^{\circ}-45^{\circ} \mathrm{N} / \mathrm{S}$ stayed longer in the interior, and the residence time was especially long
Annual obduction rate and depth, e temperature and potential density of the wintertime ML (January-March) in this region

in the Pacific due to its zonal width (Fig. 10b). It has been known that the waters below the ML in the extratropical eastern Pacific are long-lived and travel to the equatorial 

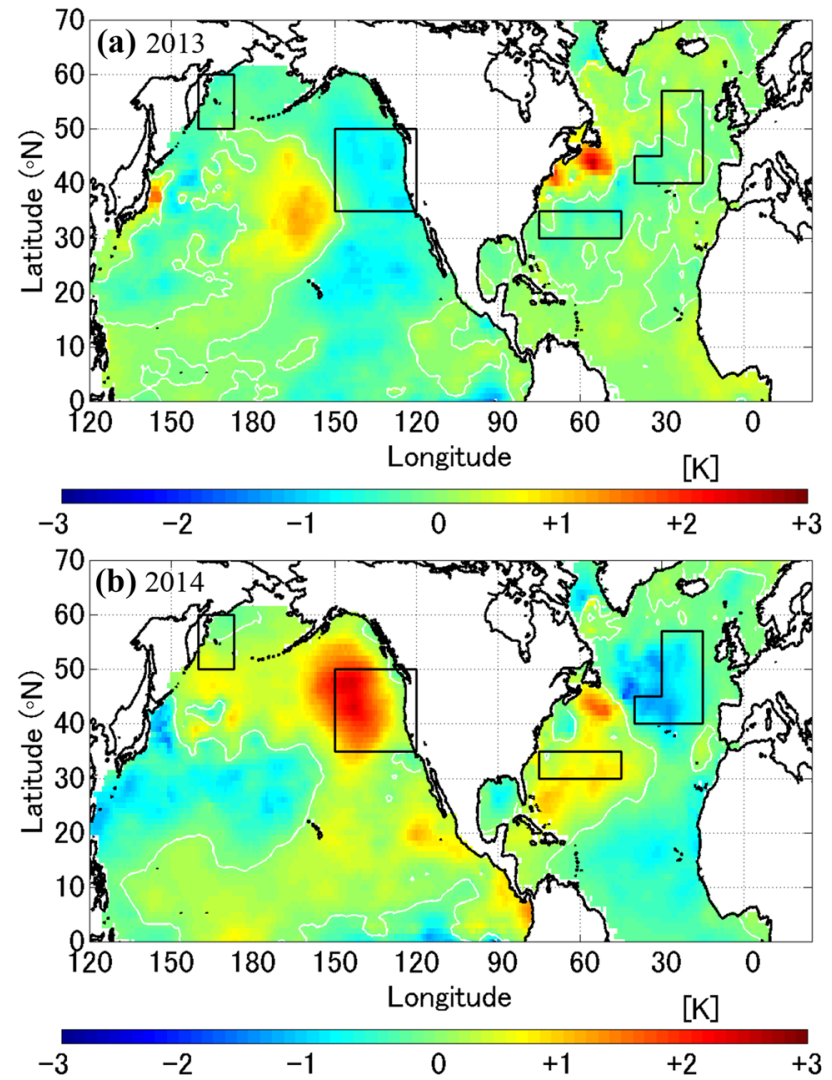

Fig. 13 Wintertime (January-March) ML temperature anomalies (K) from the average between 2004 and 2018. a 2013, b 2014, c 2015 and d 2016. The white contour denote zero. The black rectangles show

region, being assumed to play an important role in decadal variability (e.g. Gu and Philander, 1997; Sasaki et al. 2010).

The age of water obducted into the ML was larger where the ML was deeper (Fig. 10a). Besides, aged water appeared in the middle of the North and South Pacific. The southwestern Bering Sea is one of the interesting areas since salinizing effect by obducted water is the largest in the extratropics and dense and aged water comes into the surface. The water that was entrained into the ML in the area of $55^{\circ}-60^{\circ} \mathrm{N}, 160^{\circ}-173^{\circ} \mathrm{E}$ followed two different routes: from passes of the eastern Aleutian Islands, and from the northwestern North Pacific without passing through the Gulf of Alaska (Fig. 11a). The former route ("East route") must be connected to the Gulf of Alaska, but in the MOAA GPV dataset, the passes of the eastern Aleutian Islands such as Samalga Pass and Unimak Pass are not open and water cannot be traced back through them. The latter route ("South route") was traced back to around the Kuril Islands and Hokkaido along the western subarctic gyre without extending $170^{\circ} \mathrm{W}$. These two routes are consistent with the indication by Uehara et al. (2014), who examined propagation of salinity anomalies in the layer above $100 \mathrm{~m}$, while we examined the
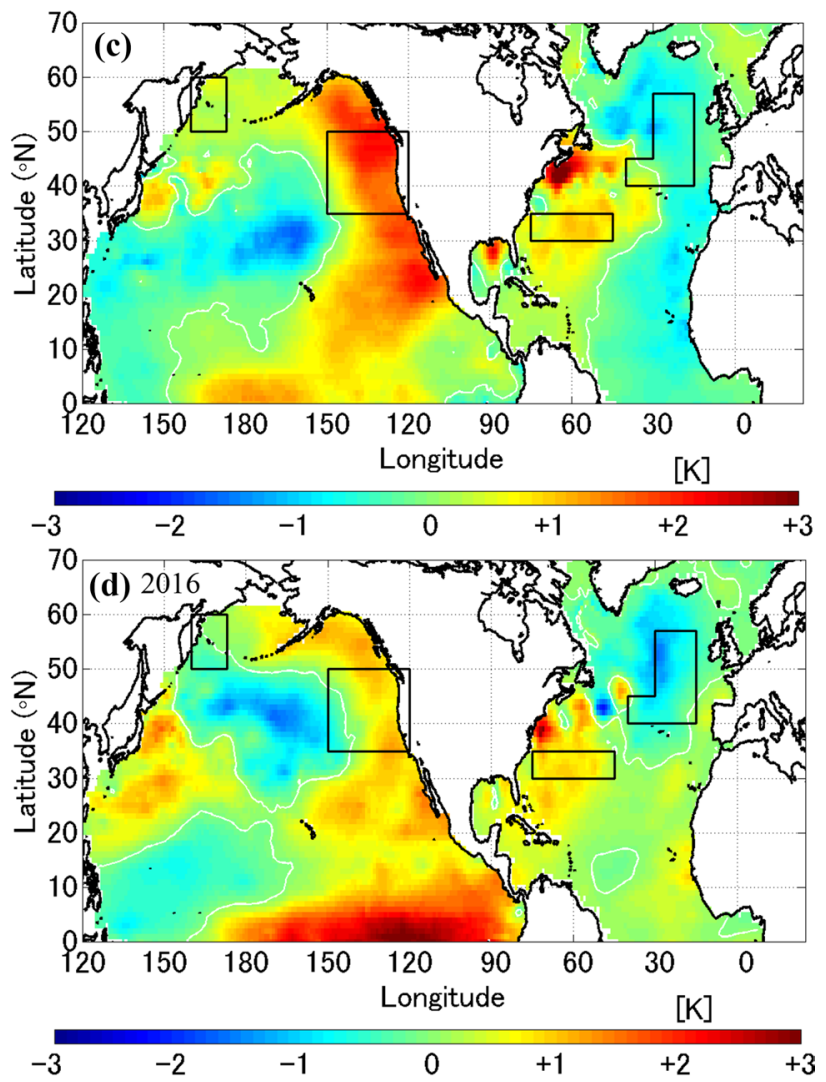

the regions where interannual changes of heat and salinity are examined in Figs. 12, 16, 18 and 19

circulation below the wintertime ML. The volume ratio of the obducted waters taking these two routes varied much depending on years (Fig. 11b). Although the water on the East route tended to be dominant, the water on the South route accounted for more than $50 \%$ of the total obduction rate in 2013-2015. After 2015, the contribution of the South-route water decreased. Water entering the Bering Sea goes through some narrow strait, where tidal mixing is dominant, and properties of the water might not be always conserved across the strait. Nevertheless, it is important to consider the differences of the route and origin of obducted water when we examine properties of the ML and material circulation.

\section{Changes after 2013 related with the Pacific warm blob event}

\subsection{Southwestern Bering Sea}

The time series of the MOAA GPV data is still not long enough to evaluate long-term trends of heat and salinity transport, but it is possible to detect changes with a time 
scale of several years. First, we focus on the southwestern Bering Sea, which is one of the areas where the effect of obduction on the ML was notable (Fig. 8). While the reentrainment term was dominant on the basis of annual mean, the obduction term affected the year-to-year variation of salinity (Fig. 12b). The obduction heating term was quite small, but its interannual variation (Fig. 12a, c) was similar to that of salinity. These variations of the obduction heating and salinizing terms naturally corresponded with those of the obduction rate and wintertime ML depth to some extent (Fig. 12d), although the former was not completely determined by the latter.

From 2013 to 2016 in the southwestern Bering Sea, the obduction heating and salinizing rates were at a low level (Fig. 12a-c). The obduction rate was small and the ML was shallow during this period, and the contribution of the southroute water to the total obduction rate was relatively large (Fig. 11b). The wintertime ML temperature was not high in 2013 (Figs. 12e, 13a), but the variation of density followed salinity rather than temperature in this region and the decrease of salinity led to shallowing of the ML (not shown) and the reduction of the obduction rate (Figs. 12d-e, 14). The heating effect due to obduction almost vanished or turned to negative, and the salinizing term became small in this period (Fig. 12c). The decreases of the obduction salinization and (E-P) in the cold season contributed to freshening the ML in 2013 (Fig. 12b), but dominant factor for the low salinity was the increase of the negative residual term in the preceding warm season (not shown), suggesting freshening by diffusions and/or large error of (E-P). More precipitation might have entered the ocean than the reanalysis value. In 2014 and 2015 the ML salinity was still low and the temperature increased, leading to the lowest density less than $26.35 \sigma_{\theta}$ (Fig. 12e). This warming around the Bering Sea in 2014-2015 appears to have been associated with the Pacific blob event that occurred in the northeastern North Pacific (Fig. 13b, c) (e.g. Bond et al. 2015; Liang et al. 2017) through a large-scale atmospheric circulation. The atmospheric condition that warms the Bering Sea changes the role of obduction in the ML budgets, and then it may have an impact on the atmosphere. It is an important subject for air-sea interaction, but this is beyond the scope of this study and left for future study.

\subsection{Northeastern Pacific}

The mean obduction rate in the region of $35^{\circ}-50^{\circ} \mathrm{N}$, $120^{\circ}-150^{\circ} \mathrm{W}$ was relatively small (Fig. 3a), and we here
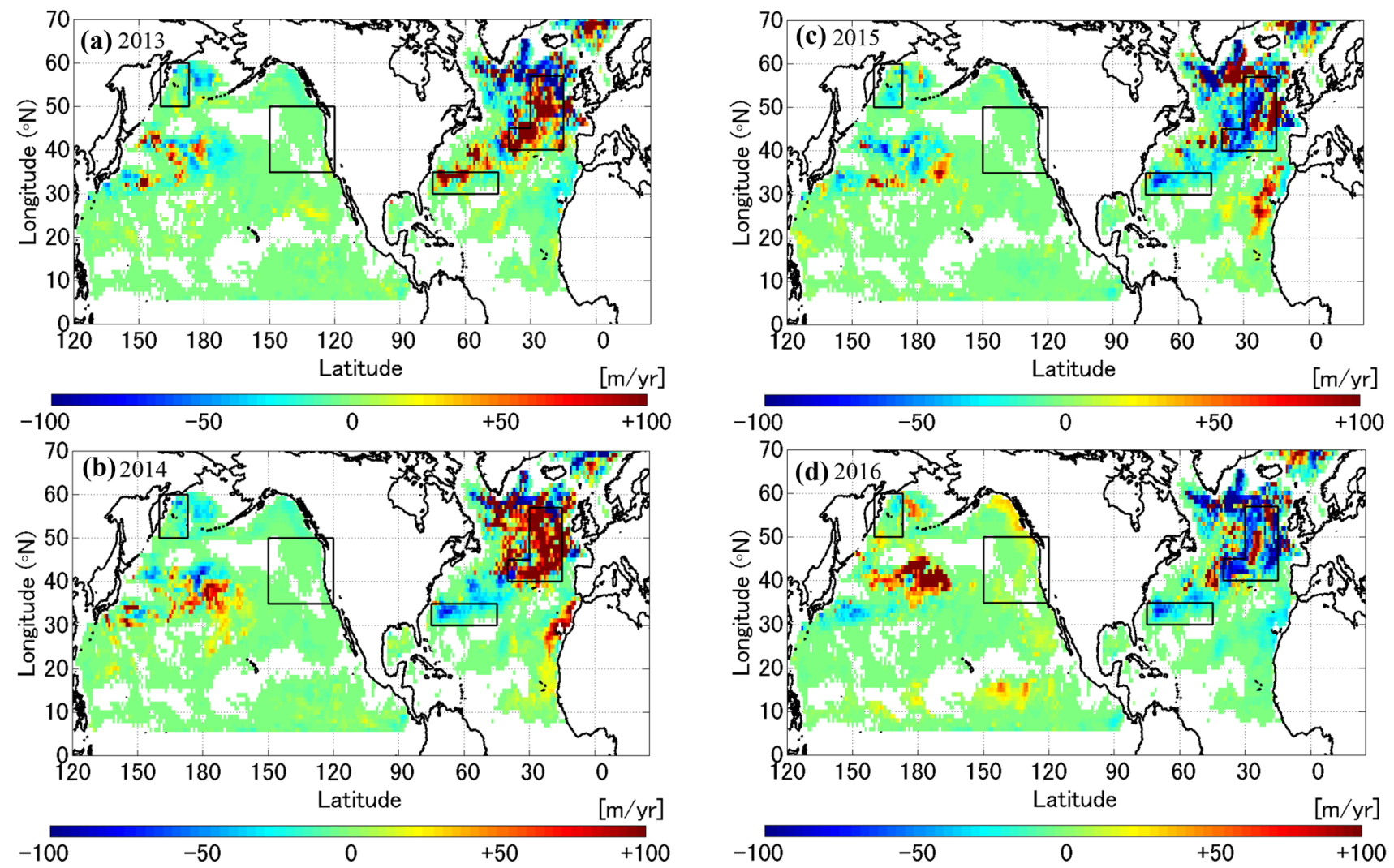

Fig. 14 Annual obduction rate anomalies from the average between 2005 and 2018. a 2013, b 2014, c 2015, and d 2016 

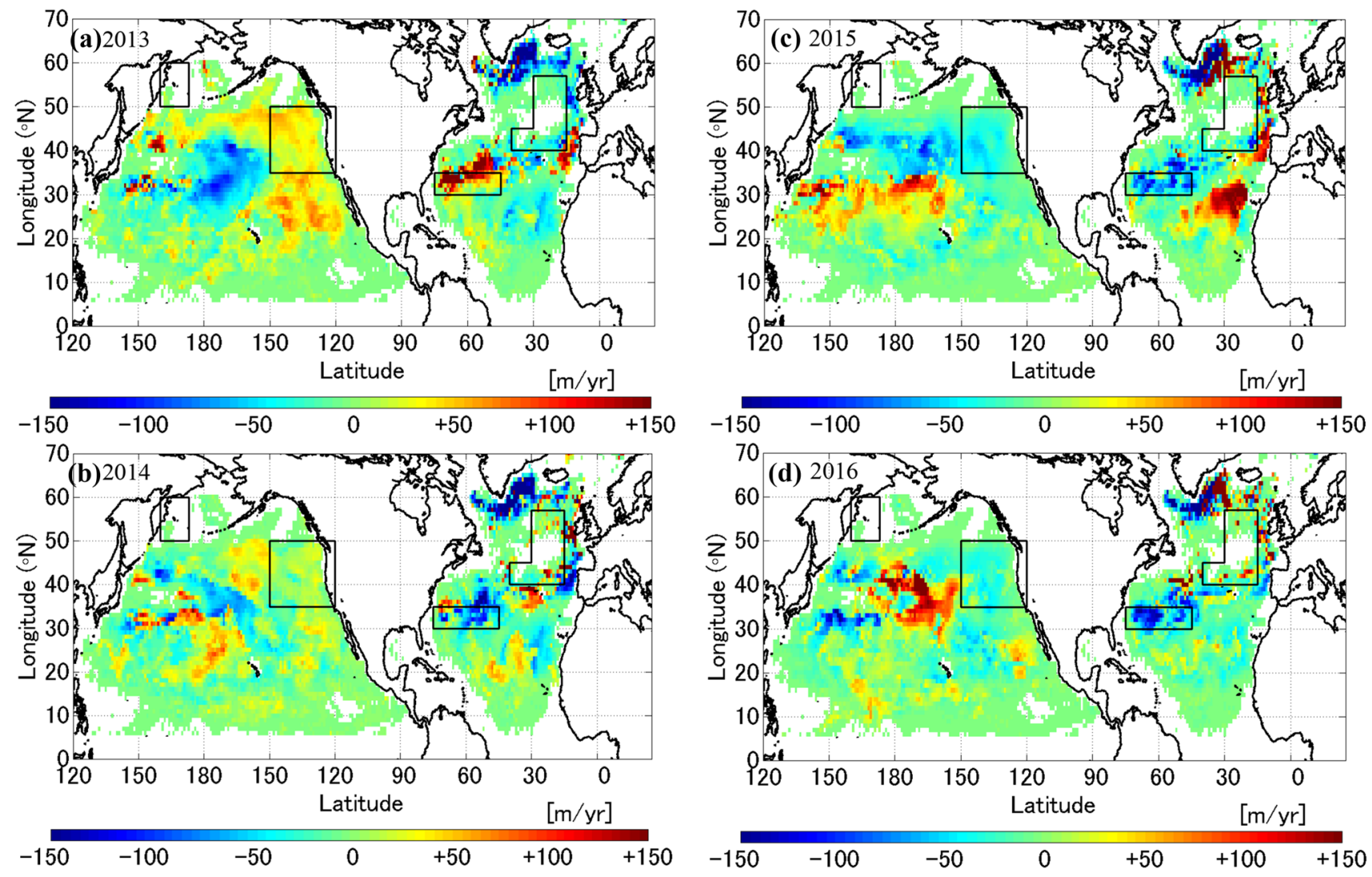

Fig. 15 Annual subduction rate anomalies from the average between 2005 and 2018. a 2013, b 2014, c 2015 and d 2016

focus the subduction process instead. The subduction rate there clearly decreased in 2015 and 2016 (Figs. 15c, d, 16a). Off the West Coast of North America, the wintertime ML became shallower by more than $15 \mathrm{~m}$ in 2014-2015 compared with that before the blob event (Fig. 16a). The subduction rate in 2014 was still at a normal level because the ML in the following winter was also quite shallow and the water that was detrained in 2014 was not entrained. The warming weakened and the ML deepened in the winter of 2016, causing subduction to almost cease in 2015. Even though the area-averaged ML depth did not much change from 2016 to 2017 , the subduction rate was still quite small in 2016 because the ML density became the largest in 2017, that is, isopycnal surfaces rose and large part of the detrained water in 2016 could not be subducted (Fig. 17a). The density of the ML was much lower in 2014 (Fig. 16b), which affected the age of the subducted water. The volume of the subducted water that was entrained into the ML again within 2 years reached $1.5 \mathrm{~Sv}$ in 2014, the largest in the analyzed period (Fig. 16a). The short-lived subducted water also increased in 2005 and 2009, reflecting the density.

\subsection{North Atlantic}

The northeastern North Atlantic off Europe is also one of the most interesting regions from the viewpoint of the obduction effects on the ML budget (Fig. 5), while subduction was scarcely caused in the North Atlantic around $50^{\circ} \mathrm{N}$ on average (Fig. 3b). The temperature and salinity change rates in the cold season correlated well with the obduction heating and salinizing, and the obduction rate reflected the ML depth (Fig. 18a-c). The ML temperature had a decreasing tendency until 2014, but the trend of density was relatively small (Fig. 18d) because a freshening trend cancelled the 

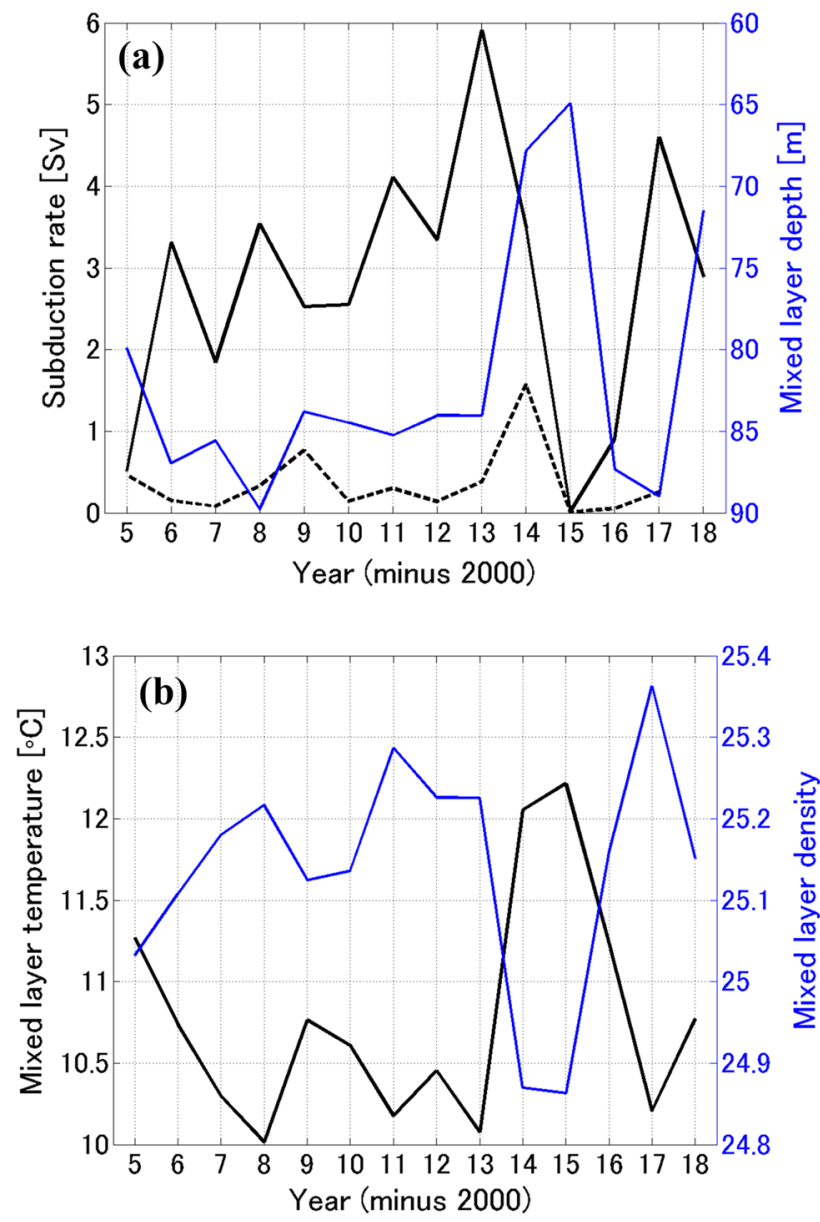

Fig. 16 a Annual subduction rate and depth, and $\mathbf{b}$ temperature and potential density of the winter (January-March) ML in the northeastern North Pacific $\left(35^{\circ}-50^{\circ} \mathrm{N}, 120^{\circ}-150^{\circ} \mathrm{W}\right)$. The black dashed line in (a) shows subducted waters that stayed below the ML for less than 2 years

temperature effect on density. The wintertime ML in 2014 became the deepest and coldest since 2005, resulting in the largest obduction rate. The cooling and freshening effects by obuction and re-entrainment were large and in phase with surface flux this year. The cold condition lasted until the spring of 2016 because the whole ML was drastically cooled in 2014 and the seasonal pycnocline remained cold. The reemergence process that the cool detrained water was entrained again was effective in making the wintertime ML cold. The ML depth and obduction rate largely decreased in 2015-2016 even though the ML density did not decline very much. The decreases were due to a rise of isopycnal surfaces (Fig. 17b). In this region, it is also interesting that while the erosion of the seasonal pycnocline made the ML saltier, that of the permanent pycnocline had the opposite role (Fig. 18b).

The spatial pattern of the ML temperature anomaly in 2014-2016 (Fig. 13b-d) is consistent with the blobregressed SST anomaly pattern shown by Liang et al. (2017): negative in the central North Pacific and the North Atlantic around $50^{\circ} \mathrm{N}$, and positive in the western North Atlantic (their Fig. 2e). The obduction and subduction anomalies approximately reflected this pattern (Figs. 14, 15). The cold anomaly in the northern North Atlantic is known as the Atlantic cold blob. Liang et al. (2017) indicated that it coincided with the Pacific warm blob through the tropical Northern Hemisphere pattern. The average domain of Fig. 18 is slightly shifted from the center of the cold blob, but the features of the variations around the center are almost the same as Fig. 18. In the western North Atlantic $\left(30^{\circ}-35^{\circ}\right.$ $\mathrm{N}, 45^{\circ}-75^{\circ} \mathrm{W}$ ), the ML density was at the lowest level in 2014-2016 due to high temperature, corresponding to the shallowest ML and the smallest obduction and subduction rates (Fig. 19). These changes are consistent with those in the Pacific blob region (Fig. 16), except that the warm condition still remained in 2016 in the western North Atlantic. Isopycnal surfaces became shallower in 2017 as in the Pacific blob region (Fig. 17a, c). The Pacific and Atlantic blob events simultaneously affected obduction and subduction, probably also material transport to/from the surface layer, through an atmospheric teleconnection pattern.

\section{Concluding remarks}

The authors quantitatively evaluated heat and salinity transport between the ML and permanent pycnocline by calculating the obduction rate with a $1^{\circ}$-grid observation dataset. The obduction rate obtained with the Eulerian definition can be directly incorporated into the ML budget equation to assess its contribution to the change rate of the ML temperature or salinity. The authors showed the heating and salinizing effects of obducted waters on the ML quantitatively based on observations for the first time.

While the mean heating rate by obduction was smaller than $\pm 0.1 \mathrm{~K} / \mathrm{yr}$ over most of the domain, it was larger than $-0.5 \mathrm{~K} / \mathrm{yr}$ in places around the Circumpolar Current, in the northeastern tropical Pacific, the southwestern tropical Indian Ocean, and the northeastern North Atlantic. The salinizing rate due to obduction exceeded $\pm 0.02 \mathrm{psu} / \mathrm{yr}$ in these areas, the subarctic North Pacific and the eastern South Pacific. Calculating transport of other materials such as carbon into the ML needs their vertical gradients (Eq. (9)), and 
(a) Northeastern North Pacific

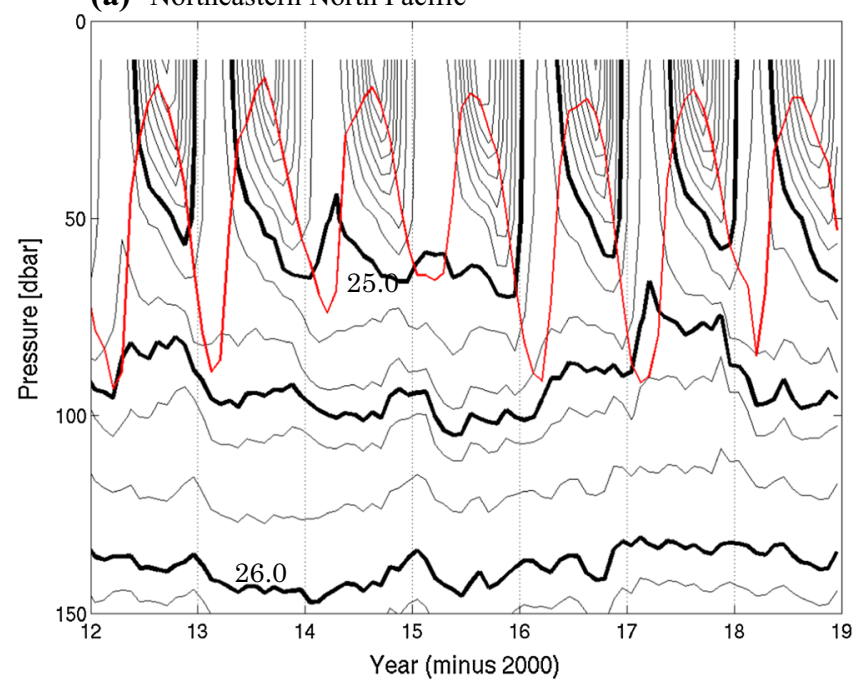

(b) Northeastern North Atlantic

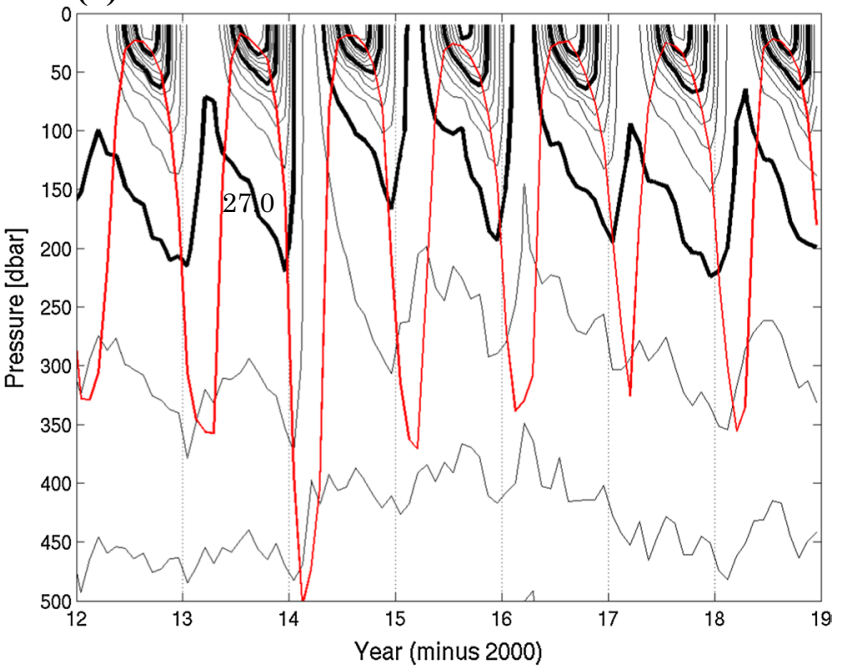

(c) Western North Atlantic

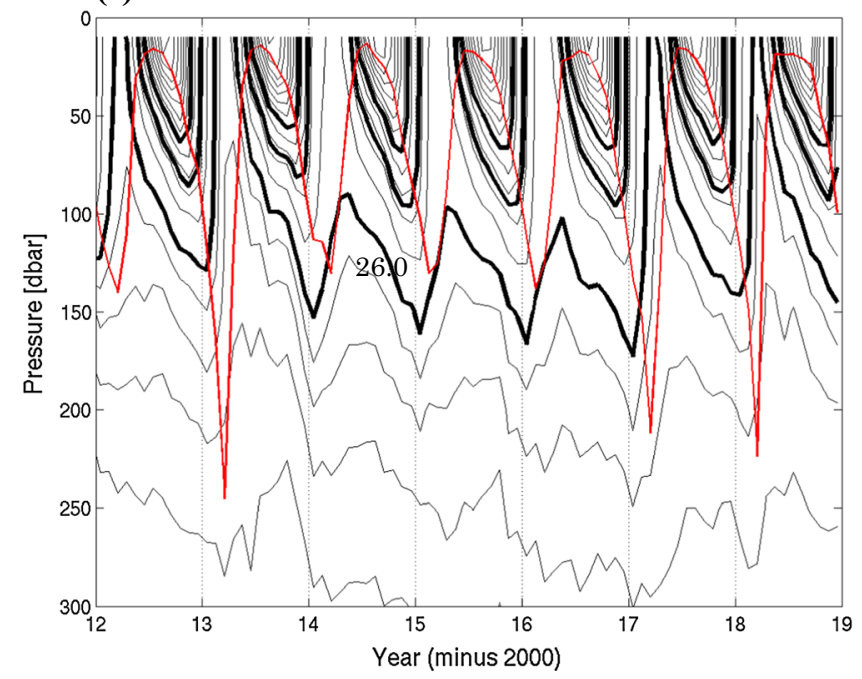

Fig. 17 Time-depth diagram of potential density. Red line denotes the ML depth. a Northeastern North Pacific $\left(35^{\circ}-50^{\circ} \mathrm{N}, 120^{\circ}-150^{\circ} \mathrm{W}\right)$, b northeastern North Atlantic $\left(40^{\circ}-45^{\circ} \mathrm{N}, 30^{\circ}-40^{\circ} \mathrm{W}\right.$ and $40^{\circ}-57^{\circ}$

we cannot show the material transport quantitatively in this study. However, Toyama et al. (2017) showed that the spatial pattern of anthropogenic carbon transport across the ML base was similar to that of net water transport (obduction minus subduction). It can be inferred that the transport of materials other than salinity is large where the obduction salinizing term is notable. The obducted waters warm and salinize the ML in the high latitudes due to the dichothermal structure. The salinizing by obduction was especially large in the southwestern Bering Sea and the Gulf of Alaska. The interannual variations of the obduction heating and
$\left.\mathrm{N}, 15^{\circ}-30^{\circ} \mathrm{W}\right)$, and $\mathbf{c}$ western North Atlantic $\left(30^{\circ}-35^{\circ} \mathrm{N}, 45^{\circ}-75^{\circ}\right.$ $\mathrm{W}$ ). The intervals of thin (bold) contours are 0.2 (1.0) to 26.0, and 0.1 (0.5) from 26.0

salinizing terms tended to correspond with that of the ML depth, but did not completely follow it. The authors briefly examined the residence time and route of the obducted or subducted waters below the ML and found that there were two different routes for the waters obducted in the southwestern Bering Sea. One can evaluate the volume and its interannual change of the obducted water on each route by the calculation with the Eulerian definition.

The history of the Argo observation network is still not long enough to detect a significant trend of heat and salinity transport between the ML and the permanent pycnocline, 

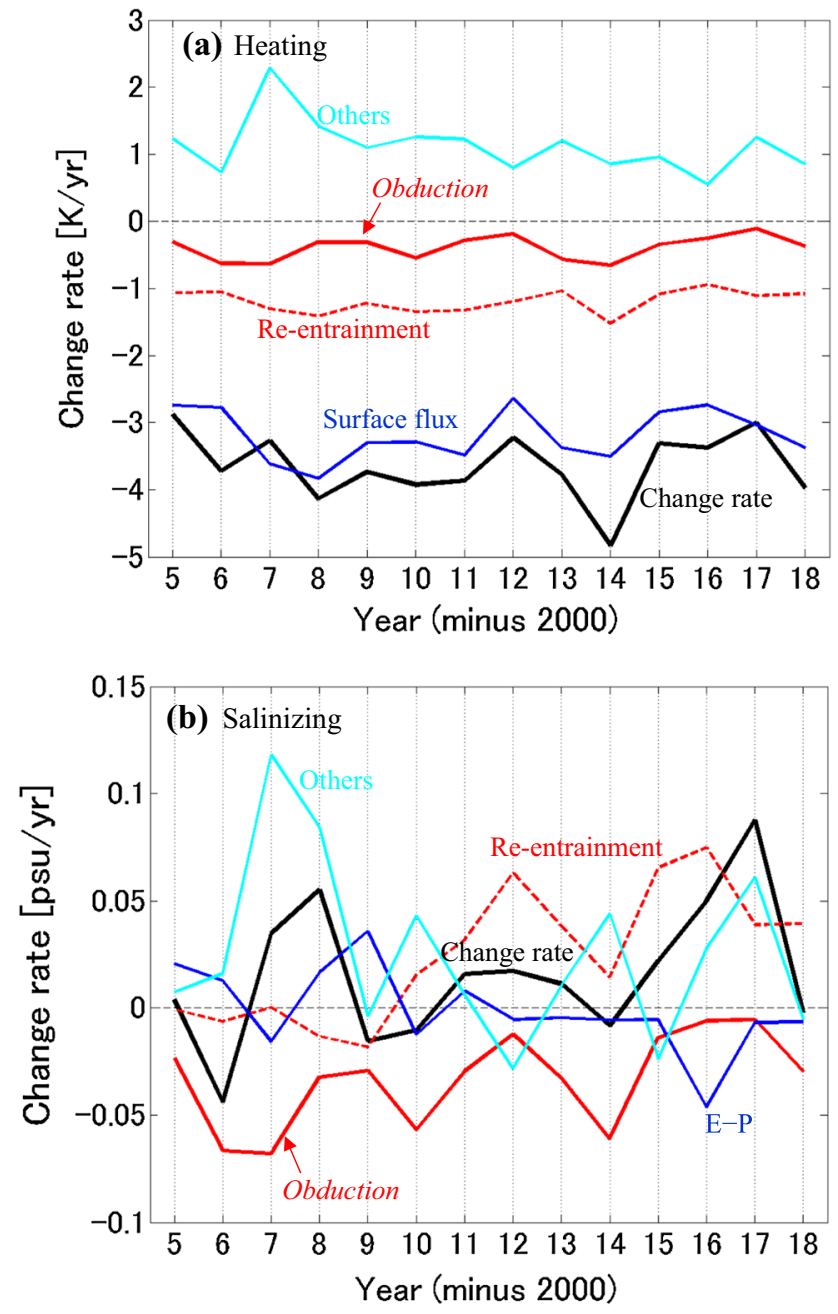

Fig. 18 a Change rate of the ML temperature and its components in the region of $40^{\circ}-45^{\circ} \mathrm{N}, 30^{\circ}-40^{\circ} \mathrm{W}$ and $40^{\circ}-57^{\circ} \mathrm{N}, 15^{\circ}-30^{\circ} \mathrm{W}$ in the northeastern North Atlantic. b As in (a), but for salinity. c Annual

but large changes with a time scale of several years can be assessed with the Argo product. The authors examined the effects of the marine heatwave in the North Pacific on subcution and obduction as a case study. The famous "blob" event occurred around the Gulf of Alaska in 2014-2016. In the region of $35^{\circ}-50^{\circ} \mathrm{N}, 120^{\circ}-150^{\circ} \mathrm{W}$, the wintertime $\mathrm{ML}$ became shallower by more than $15 \mathrm{~m}$ in 2014-2015 compared with that before the blob event, and subduction almost ceased in 2015. The subduction rate in 2014 was still at the normal level because the ML in the following winter was also shallow and the water that was detrained in 2014 was not entrained, but nearly half of the water subducted in 2014 was eroded within only 2 years. Although the wintertime ML depth returned to the average level in 2016, the subduction rate was still low due to a rise of isopycnal surfaces. The subduction rate in this region recovered in 2017. The effect of the blob event spread to the southwestern Bering
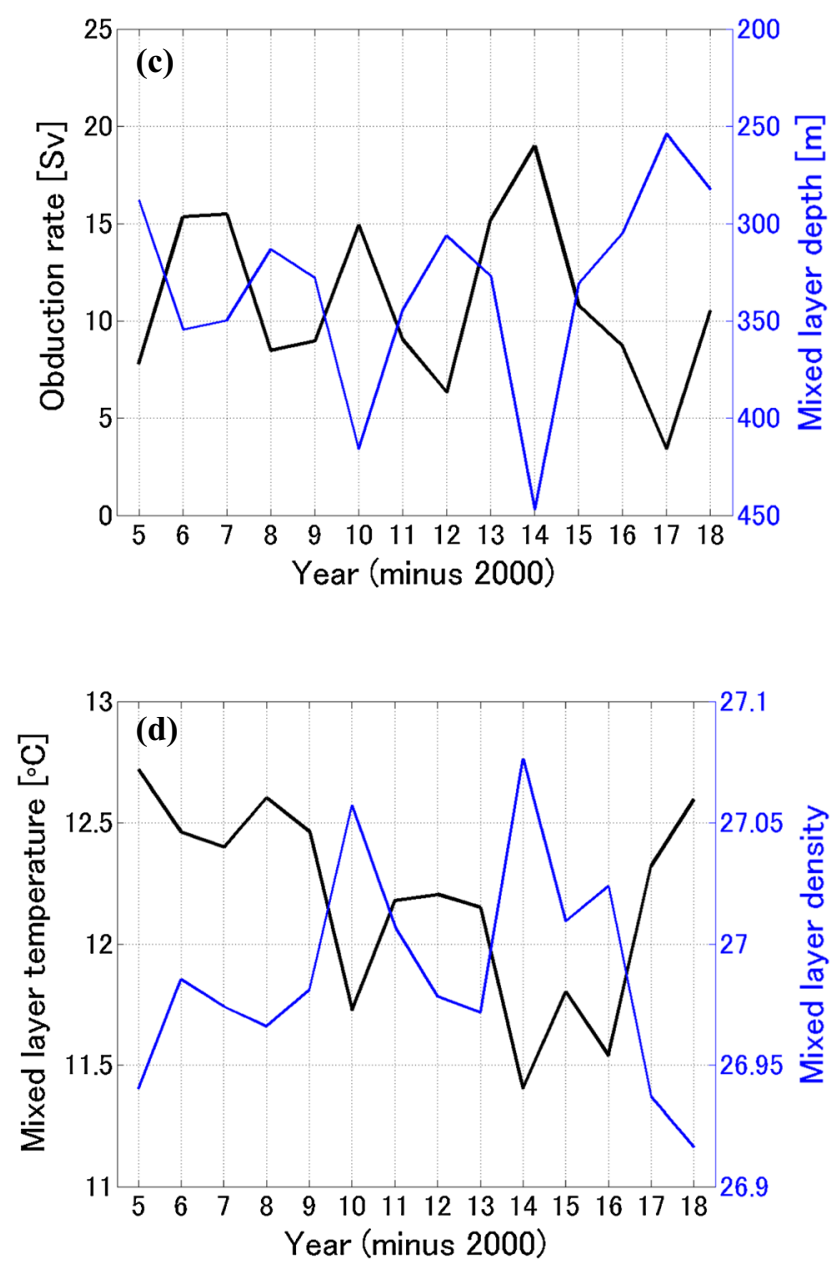

obduction rate and depth, and $\mathbf{d}$ temperature and potential density of the wintertime (January-March) ML

Sea, where the wintertime ML temperature increased and the obduction rate decreased in 2014-2015, although the ML was already shallow in 2013 due to lower salinity. In the western North Atlantic, the ML became shallower and the obduction and subduction rates decreased simultaneously with the Pacific blob. On the other hand, a cold SST anomaly in the northeastern North Atlantic coincided with the Pacific blob, and the ML depth and obduction rate became the maximum in the winter of 2014. The cold condition lasted for nearly 3 years, but the ML depth and obduction rate largely decreased in 2015-2016 due to a rise of isopycnal surfaces. This region had an interesting feature that while the re-entrainment of the seasonal pycnocline made the ML saltier, obduction played the opposite role. An atmospheric teleconnection pattern caused the Pacific and Atlantic blob events simultaneously, resulting in large changes in water mass exchanges across the ML base. We need to examine in 

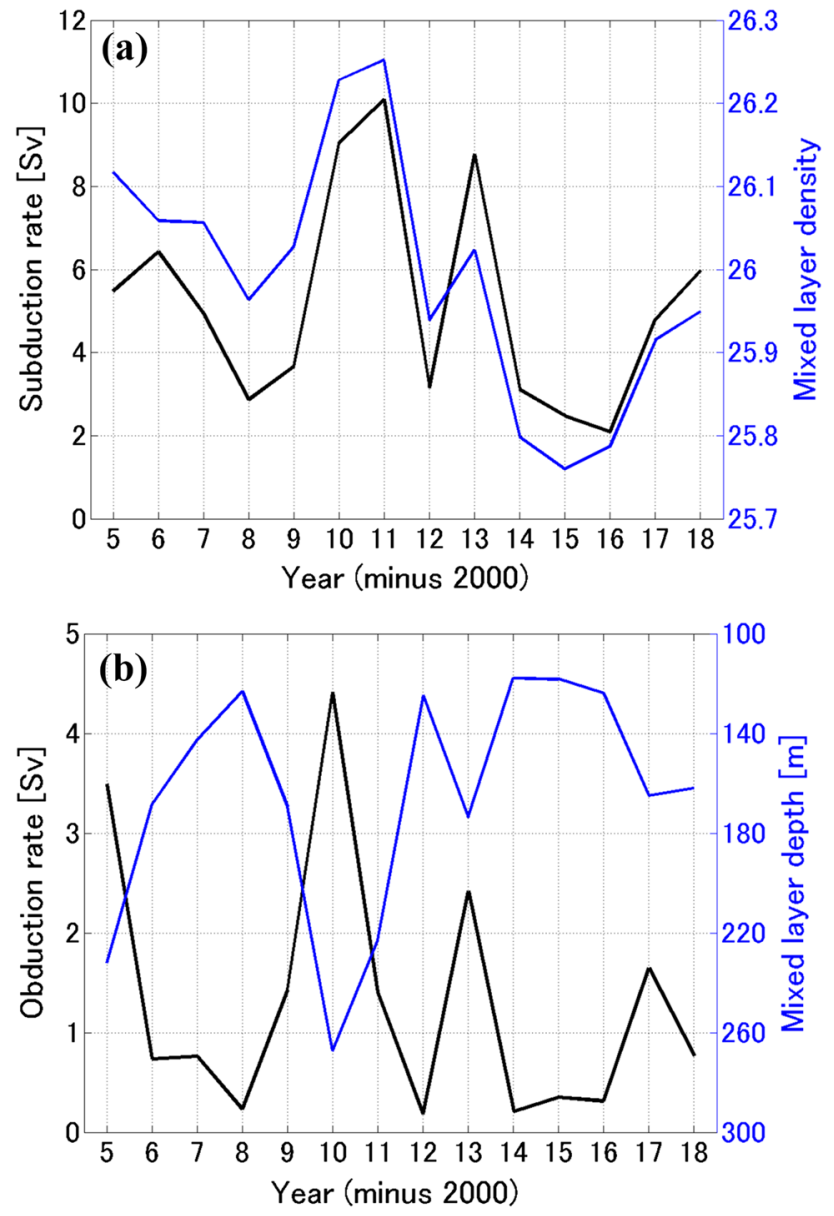

Fig. 19 a Annual subduction and $\mathbf{b}$ obduction rates in the western North Atlantic $\left(30^{\circ}-35^{\circ} \mathrm{N}, 45^{\circ}-75^{\circ} \mathrm{W}\right)$. The potential density and depth of the wintertime ML are shown in (a) and (b), respectively

the next step whether the obduction/subduction processes give feedback to the atmosphere.

Acknowledgements This work was supported by the Ministry of Education, Culture, Sports, Science and Technology (MEXT) of Japan, Grant-in-Aid for Scientific Research on Innovative Areas (19H05700), and the Japan Society for the Promotion of Science (JSPS) Grants-inAid for Scientific Research (A) (KAKENHI) (18H03726). The ERAinterim data were supplied by the ECMWF (https://www.ecmwf.int/ en/forecasts/datasets/reanalysis-datasets/era-interim). Members of the Argo data management team in the Research Institute for Global Change of the Japan Agency for Marine-Earth Science and Technology (JAMSTEC) helped with the use of Argo float data and the refinement of the dataset MOAA GPV (http://www.jamstec.go.jp/ARGO/ argo_web/argo/?page_id=80\&lang=en). The authors appreciate valuable comments by anonymous reviewers and an editor.

Open Access This article is licensed under a Creative Commons Attribution 4.0 International License, which permits use, sharing, adaptation, distribution and reproduction in any medium or format, as long as you give appropriate credit to the original author(s) and the source, provide a link to the Creative Commons licence, and indicate if changes were made. The images or other third party material in this article are included in the article's Creative Commons licence, unless indicated otherwise in a credit line to the material. If material is not included in the article's Creative Commons licence and your intended use is not permitted by statutory regulation or exceeds the permitted use, you will need to obtain permission directly from the copyright holder. To view a copy of this licence, visit http://creativecommons.org/licenses/by/4.0/.

\section{References}

Akima H (1970) A new method for interpolation and smooth curve fitting based on local procedures. J Assoc Comput Mech 17:589-603

Alexander MA, Deser C (1995) A mechanism for the recurrence of wintertime midlatitude SST anomalies. J Phys Oceanogr 25:122-137. https://doi.org/10.1175/1520-0485(1995)025\%3c012 2:AMFTRO \%3e2.0.CO;2

Argo (2020) Argo float data and metadata from Global Data Assembly Centre (Argo GDAC). SEANOE. https://doi.org/10.17882/42182

Bates NR (2012) Multi-decadal uptake of carbon dioxide into subtropical mode water of the North Atlantic Ocean. Biogeosciences 9:2649-2659. https://doi.org/10.5194/bg-9-2649-2012

Berrisford P, Dee D, Poli P, Brugge R, Fielding K, Fuentes M, Kållberg P, Kobayashi S, Uppala S, Simmons A (2011) The ERAInterim archive Version 2.0. ERA report series. 1. Technical report. ECMWF, pp.23, https://www.ecmwf.int/file/21498/ download?token $=$ cr $31 \mathrm{Wrx} 8$

Blanke B, Speich S, Madec G, Maugé R (2002) A global diagnostic of interior ocean ventilation. Geophys Res Lett 29:1267. https ://doi.org/10.1029/2001GL013727

Bond NA, Cronin MF, Freeland H, Mantua N (2015) Causes and impacts of the 2014 warm anomaly in the NE Pacific. Geophys Res Lett 42:3414-3420. https://doi.org/10.1002/2015GL063306

Byju P, Dommenget D, Alexander MA (2018) Widespread reemergence of sea surface temperature anomalies in the global oceans, including tropical regions forced by reemerging winds. Geophys Res Lett 45:7683-7691. https://doi.org/10.1029/2018GL079137

Cassou C, Deser C, Alexander MA (2007) Investigating the impact of reemerging sea surface temperature anomalies on the winter atmospheric circulation over the North Atlantic. J Clim 20:3510-3526. https://doi.org/10.1175/JCLI4202.1

Cronin MF, Bond NA, Farrar JT, Ichikawa H, Jayne SR, Kawai Y, Konda M, Qiu B, Rainville L, Tomita H (2013) Formation and erosion of the seasonal thermocline in the Kuroshio Extension recirculation gyre. Deep-Sea Res II 85:62-74. https://doi. org/10.1016/j.dsr2.2012.07.018

Cushman-Roisin B (1987) Subduction. Dynamics of the oceanic surface mixed layer: Proc. 'Aha Huliko'a Hawaiian Winter Workshop, Honolulu, HI, University of Hawai 'i at Mānoa, pp 181-196. http://www.soest.hawaii.edu/PubServices/1987pdfs/ Cushman_Roisin.pdf

de Coëtlogon G, Frankignoul C (2003) The persistence of winter sea surface temperature in the North Atlantic. J Clim 16:13641377. https://doi.org/10.1175/1520-0442-16.9.1364

Frölicher TL, Fischer EM, Gruber N (2018) Marine heatwaves under global warming. Nature 560:360-364. https://doi.org/10.1038/ s41586-018-0383-9

Gu D, Philander SGH (1997) Interdecadal climate fluctuations that depend on exchanges between the tropics and extratropics. Science 275:805-807

Hanawa K, Sugimoto S (2004) 'Reemergence' areas of winter sea surface temperature anomalies in the world's oceans. Geophys Res Lett 31:L10303. https://doi.org/10.1029/2004GL019904 
Hanawa K, Talley LD (2001) Mode waters. Ocean circulation and climate. In: Siedler G, Church J, Gould J (eds) International geophysics series, vol 77. Academic Press, New York, pp 373-386

Hosoda S, Ohira T, Nakamura T (2008) A monthly mean dataset of global oceanic temperature and salinity derived from Argo float observations. JAMSTEC Rep Res Dev 8:47-59. https://doi. org/10.5918/jamstecr.8.47

Karstensen J, Quadfasel D (2002) Formation of southern hemisphere thermocline waters: Water mass conversion and subduction. $\mathrm{J}$ Phys Oceanogr 32:3020-3038. https://doi.org/10.1175/15200485(2002)032\%3c3020:FOSHTW\%3e2.0.CO;2

Katsura S, Oka E, Qiu B, Schneider N (2013) Formation and subduction of North Pacific Tropical Water and their interannual variability. J Phys Oceanogr 43:2400-2415. https://doi.org/10.1175/ JPO-D-13-031.1

Kouketsu S, Doi T, Kawano T, Masuda S, Sugiura N, Sasaki Y, Toyoda T, Igarashi H, Kawai Y, Katsumata K, Uchida H, Fukasawa M, Awaji T (2011) Deep ocean heat content changes estimated from observation and reanalysis product and their influence on sea level change. J Geophys Res 116:C03012. https://doi. org/10.1029/2010JC006464

Levitus S (1982) Climatological Atlas of the World Ocean. NOAA Prof. Paper 13, pp 173 and 17 microfiche, ftp://ftp.nodc.noaa. gov/pub/data.nodc/woa/PUBLICATIONS/levitus_atlas_1982.pdf

Levitus S, Antonov JI, Boyer TP, Baranova OK, Garcia HE, Locarnini RA, Mishonov AV, Reagan JR, Seidov D, Yarosh ES, Zweng MM (2012) World ocean heat content and thermosteric sea level change (0-2000 m), 1955-2010. Geophys Res Lett 39:L10603. https://doi.org/10.1029/2012GL051106

Liang Y-C, Yu J-Y, Saltzman ES, Wang F (2017) Linking the tropical Northern Hemisphere pattern to the Pacific warm blob and Atlantic cold blob. J Clim 30:9041-9057. https://doi.org/10.1175/ JCLI-D-17-0149.1

Liu LL, Huang RX (2012) The global subduction/obduction rates: their interannual and decadal variability. J Clim 25:1096-1115. https:// doi.org/10.1175/2011JCLI4228.1

Liu LL, Wang F, Huang RX (2011) Enhancement of subduction/obduction due to hurricane-induced mixed layer deepening. Deep-Sea Res I 58:658-667. https://doi.org/10.1016/j.dsr.2011.04.003

Liu LL, Huang RX, Wang F (2016) Subduction/obduction rate in the North Pacific diagnosed by an eddy-resolving model. Chin J Oceanol Limnol 34:835-846. https://doi.org/10.1007/s0034 3-016-5036-y

Marchall JC, Nurser AJG, Williams RG (1993) Inferring the subduction rate and period over the North Atlantic. J Phys Oceanogr 23:1315-1329. https://doi.org/10.1175/15200485(1993)023\%3c1315:ITSRAP\%3e2.0.CO;2

Namias J, Born RM (1970) Temporal coherence in North Pacific sea-surface temperature patterns. J Geophys Res 75:5952-5955. https://doi.org/10.1029/JC075i030p05952

Nishikawa S, Tsujino H, Sakamoto K, Nakano H (2010) Effects of mesoscale eddies on subduction and distribution of subtropical mode water in an eddy-resolving OGCM of the western North Pacific. J Phys Oceanogr 40:1748-1765

Oka E, Kouketsu S, Yanagimoto D, Ito D, Kawai Y, Sugimoto S, Qiu B (2020) Formation of central mode water based on two zonal hydrographic sections in spring 2013 and 2016. J Oceanogr. https://doi.org/10.1007/s10872-020-00551-9 (in press)

Oliver ECJ, Donat MG, Burrows MT, Moore PJ, Smale DA, Alexander LV, Benthuysen JA, Feng M, Gupta AS, Hobday AJ, Holbrook
NJ, Perkins-Kirkpatrick SE, Scannell HA, Straub SC, Wernberg $\mathrm{T}$ (2018) Longer and more frequent marine heatwaves over the past century. Nat Commun 9:1324. https://doi.org/10.1038/s4146 7-018-03732-9

Qiu B, Huang RX (1995) Ventilation of the North Atlantic and North Pacific: subduction versus obduction. J Phys Oceanogr 25:23742390. https://doi.org/10.1175/1520-0485(1995)025\%3c237 4:VOTNAA\%3e2.0.CO;2

Qiu B, Kelly KA (1993) Upper-ocean heat balance in the Kuroshio Extension region. J Phys Oceanogr 23:2027-2041

Qiu B, Hacker P, Chen S, Donohue KA, Watts DR, Mitsudera H, Hogg NG, Jayne SR (2006) Observations of the subtropical mode water evolution from the Kuroshio Extension System Study. J Phys Oceanogr 36:457-473. https://doi.org/10.1175/JPO2849.1

Ren L, Riser SC (2009) Seasonal salt budget in the northeast Pacific Ocean. J Geophys Res 114:C12004. https://doi.org/10.1029/2009J C005307

Rhein M, Rintoul SR, Aoki S, Campos E, Chambers D, Feely RA, Gulev S, Johnson GC, Josey SA, Kostianoy A, Mauritzen C, Roemmich D, Talley LD, Wang F (2013) Observations: ocean. In: Stocker TF, Qin D, Plattner G-K, Tignor M, Allen SK, Boschung J, Nauels A, Xia Y, Bex V, Midgley PM (eds) Climate change 2013: the physical science basis. Contribution of working group I to the fifth assessment report of the intergovernmental panel on climate change. Cambridge University Press, Cambridge

Sasaki YN, Schneider N, Maximenko N, Lebedev K (2010) Observational evidence for propagation of decadal spiciness anomalies in the North Pacific. Geophys Res Lett 37:L07708. https://doi. org/10.1029/2010GL042716

Suga T, Aoki Y, Saito H, Hanawa K (2008) Ventilation of the North Pacific subtropical pycnocline and mode water formation. Prog Oceanogr 77:285-297. https://doi.org/10.1016/j-pocea n.2006.12.005

Sugimoto S, Hanawa K (2005) Remote reemergence areas of winter sea surface temperature anomalies in the North Pacific. Geophys Res Lett 32:L01606. https://doi.org/10.1029/2004GL021410

Sugimoto S, Hanawa K, Watanabe T, Suga T, Xie S-P (2017) Enhanced warming of the subtropical mode water in the North Pacific and North Atlantic. Nat Clim Change 7:656-658. https://doi. org/10.1038/nclimate3371

Taws SL, March R, Wells NC, Hirschi J (2011) Re-emerging ocean temperature anomalies in late-2010 associated with a repeat negative NAO. Geophys Res Lett 38:L20601. https://doi. org/10.1029/2011GL048978

Toyama K, Iwasaki A, Suga T (2015) Interannual variation of annual subduction rate in the North Pacific estimated from a gridded Argo product. J Phys Oceanogr 45:2276-2293. https://doi. org/10.1175/JPO-D-14-0223.1

Toyama K, Rodgers KB, Blanke B, Iudicone D, Ishii M, Aumont O, Sarmiento JL (2017) Large reemergence of anthropogenic carbon into the ocean's surface mixed layer sustained by the ocean's overturning circulation. J Clim 30:8615-8631. https://doi.org/10.1175/ JCLI-D-16-0725.1

Uehara H, Kruts AA, Mitsudera H, Nakamura T, Volkov YN, Wakatsuchi M (2014) Remotely propagating salinity anomaly varies the source of North Pacific ventilation. Prog Oceanogr 126:80-97. https://doi.org/10.1016/j.pocean.2014.04.016

Zhang H-M, Hogg NG (1992) Circulation and water mass balance in the Brazil basin. J Mar Res 50:385-420. https://doi. org/10.1357/002224092784797629 